\title{
Modulation of cerebral endothelial cell function by TGF- $\beta$ in glioblastoma: VEGF-dependent angiogenesis versus endothelial mesenchymal transition
}

\author{
Shanmugarajan Krishnan ${ }^{1}$, Emese Szabo ${ }^{1}$, Isabel Burghardt ${ }^{1}$, Karl Frei ${ }^{2}$, Ghazaleh \\ Tabatabai ${ }^{1,3}{ }^{\text {, Michael Weller }}{ }^{1}$ \\ ${ }^{1}$ Laboratory of Molecular Neuro-Oncology, Department of Neurology and Neuroscience Center, University Hospital and \\ University of Zurich, Zurich, Switzerland \\ ${ }^{2}$ Laboratory of Molecular Neuro-Oncology, Department of Neurosurgery and Neuroscience Center, University Hospital and \\ University of Zurich, Zurich, Switzerland \\ ${ }^{3}$ Interdisciplinary Division of Neuro-Oncology, Departments of Vascular Neurology and Neurosurgery, University Hospital \\ Tübingen, Tübingen, Germany
}

Correspondence to:

Michael Weller, e-mail: michael.weller@usz.ch

Keywords: angiogenesis, glioblastoma, TGF- $\beta$, VEGF, PIGF

Received: January 26, $2015 \quad$ Accepted: June 03, $2015 \quad$ Published: June 15, 2015

\section{ABSTRACT}

Glioblastoma are among the most angiogenic tumors. The molecular mechanisms that control blood vessel formation by endothelial cells (EC) in glioblastoma remain incompletely understood. Transforming growth factor- $\beta$ (TGF- $\beta$ ) is a key regulatory cytokine that has proinvasive and stemness-maintaining autocrine properties in glioblastoma and confers immunosuppression to the tumor microenvironment. Here we characterize potential pro- and anti-angiogenic activities of TGF- $\beta$ in the context of glioblastoma in vitro, using human brain-derived microvascular endothelial cells (hCMEC/D3) and glioblastoma-derived endothelial cells (GMEC) as model systems. We find that TGF- $\beta$ induces vascular endothelial growth factor (VEGF) and placental growth factor (PIGF) mRNA expression and protein release in a TGF- $\beta$ receptor (T $\beta R$ ) II / activin-like kinase (ALK)-5-dependent manner under normoxia and hypoxia, defining potential indirect proangiogenic activity of TGF- $\beta$ in glioblastoma. In parallel, exogenous TGF- $\beta$ has also inhibitory effects on EC properties and induces endothelialmesenchymal transition (EndMT) in hCMEC and GMEC. Accordingly, direct inhibition of endogenous TGF- $\beta$ /ALK- 5 signalling increases EC properties such as tube formation, von-Willebrand factor (VWF) and claudin (CLDN) 5 expression. Yet, the supernatant of TGF- $\beta$-stimulated hCMEC and GMEC strongly promotes EC-related gene expression and tube formation in a cediranib-sensitive manner. These observations shed light on the complex pro- and anti-angiogenic pathways involving the cross-talk between TGF- $\beta$ and VEGF/PLGF signalling in glioblastoma which may involve parallel stimulation of angiogenesis and EndMT in distinct target cell populations.

\section{INTRODUCTION}

Blood supply is an essential prerequisite for solid tumor growth and therefore a bona fide target for intervention. The processes by which tumors initiate and maintain their blood supply are complex and have remained incompletely understood. Vasculogenesis is defined as the initial migration and differentiation of endothelial precursor cells to form blood vessels de novo. Subsequent to this, angiogenesis occurs by the formation of new blood vessels from pre-existing ones, also termed sprouting angiogenesis. Angiogenesis in glioblastoma is characterized by a neovasculature that has an erratic basement membrane, reduced pericyte coverage, decreased astrocytic end feet association with blood vessels, and altered expression of adhesion molecules on endothelial cells (EC) [1]. This abnormal vascularization causes excessive leakiness and promotes edema formation. 
One traditional view states that hypoxic tumor cells release vascular endothelial growth factor (VEGF) which in turn counteracts tumor hypoxia by mediating the growth of new blood vessels. However, it is unlikely that all blood vessel formation in glioblastoma is triggered by hypoxiamediated VEGF signaling, notably early in the disease course when there is probably little hypoxia. Thus, alternative pathways regulating tumor-associated angiogenesis beyond hypoxia-driven VEGF synthesis are likely to exist.

Transforming growth factor (TGF)- $\beta$ is a prototype member of a cytokine family involved in most cancerassociated processes. In glioblastoma, immunosuppression and autocrine control of migration, invasiveness and stemness have received most attention. However, TGF- $\beta$ has also been implicated in angiogenesis in various model systems including physiological and pathological angiogenesis. Direct TGF- $\beta$ signalling on endothelial cells has been linked mainly to two type I receptors, activin-like receptor kinases (ALK)-1 and ALK-5. These two TGF $\beta$ R I-mediated pathways have been attributed to opposing effects in response to TGF- $\beta$ : ALK-1 on interaction with T $\beta$ RII induced Smad 1/5 phosphorylation to induce endothelial cell proliferation [2] and migration [3] whereas ALK-5 recruited by T $\beta$ RII induces Smad 2/3 phosphorylation, thereby inhibiting the above-mentioned effects [3]. TGF- $\beta$ family ligands can interact with coreceptors represented by endoglin (CD105), which is highly expressed in proliferating endothelial cells, and betaglycan (T $\beta$ RIII). In the present study, we investigated the interaction and dependence of these key signaling pathways and their role for glioma angiogenesis, using hCMEC and GMEC as models.

\section{RESULTS}

\section{hCMEC express TGF- $\beta$ receptors and coreceptors}

We first analysed whether TGF- $\beta$ receptors (T $\beta$ RII, ALK-1 and ALK-5) and co-receptors (endoglin and T $\beta$ RIII) were expressed at mRNA and protein level in hCMEC. All receptors were expressed at mRNA level under normoxia and hypoxia, without significant differences $(p>0.05)$ (Figure 1A). T $\beta$ RII, endoglin and T $\beta$ RIII protein levels were also unaltered in hypoxia (Figure 1B-1D). Hypoxia decreased pSmad1/5 and Smad5 levels, but did not affect pSmad2, Smad2, Smad1 or secreted levels of TGF- $\beta$. Like most non-neoplastic cells, hCMEC released more unprocessed than active TGF- $\beta$ (Supplementary Figure 1A).

After confirming the expression of the TGF- $\beta$ receptors and ligand, we transiently silenced T $\beta$ RII, ALK1 , ALK-5, endoglin or T $\beta$ RIII in the absence or presence of TGF- $\beta$. Silencing was confirmed at the mRNA and protein levels wherever feasible (Figure 1E-1F). The specificity of silencing ALK-1 versus ALK-5 was verified by RT-PCR
(Supplementary Figure 1B-1C). Interestingly, exposure to exogenous TGF- $\beta$ decreased T $\beta$ RIII and increased ALK-5 at mRNA level and endoglin expression at mRNA and protein levels. Constitutive pSmad2 was faintly detectable and not induced by receptor silencing. Constitutive $\mathrm{pSmad} 1 / 5$ levels increased mildly with silencing of endoglin, but not with silencing of the other receptors (Figure 1E-1F). TGF- $\beta$ strongly induced $\mathrm{pSmad} 2$, and this induction was attenuated by the silencing of T $\beta$ RII, ALK-1, ALK-5 or endoglin, although not T $\beta$ RIII. TGF- $\beta$ strongly decreased $\mathrm{pSmad} 1 / 5$ levels, and this effect was attenuated somewhat by the silencing of ALK-1, ALK-5, T $\beta$ RII, T $\beta$ RIII or endoglin, but robustly by SD-208. T $\beta$ RII levels were strongly reduced at 72 $h$ after exposure to TGF- $\beta$ (Figure 1F).

Under these experimental conditions, exposure of hCMEC to TGF- $\beta$ did not induce significant loss of viability assessed by trypan blue dye exclusion, cell cycle arrest assessed by PI staining or features of apoptosis as assessed by annexin $\mathrm{V} /$ propidium labeling (Supplementary Figure 2).

\section{TGF- $\beta$ induces VEGF $m$ RNA expression and protein release in hCMEC under normoxic and hypoxic conditions}

We next investigated the effect of recombinant TGF- $\beta$ on VEGF expression in hCMEC at increasing concentrations for $24 \mathrm{~h}$ either at normoxia or under hypoxic conditions $\left(1 \% \mathrm{O}_{2}\right)$. VEGF mRNA expression and protein release were increased approximately 10 fold when the cells were shifted to hypoxia. Exposure to TGF- $\beta$ increased VEGF mRNA expression and protein release in a concentration- and time-dependent manner, more significantly even in hypoxia than under normoxic conditions (Figure 2A-2D). The lowest concentration of TGF- $\beta(0.1 \mathrm{ng} / \mathrm{ml})$ did not increase VEGF protein in normoxia whereas the increase was significant in hypoxia. The induction of VEGF mRNA expression was not restricted to a specific VEGF isoform (Figure 2E). Hypoxia increased PlGF mRNA expression, moreover, the combination of hypoxia and TGF- $\beta$ resulted in a further enhancement compared to hypoxia or TGF- $\beta$ alone (Figure 2F). PIGF release was increased by TGF- $\beta$ or hypoxia, and the combination was more effective than either treatment alone (Figure 2G).

\section{TGF- $\beta$-mediated induction of VEGF mRNA and release in hCMEC involves T $\beta R I I, A L K-5$ and T $\beta R I I I$}

To determine the relative contribution of TGF- $\beta$ receptors and co-receptors to the TGF- $\beta$-mediated increase of VEGF and PlGF in hCMEC, we examined their modulation by gene silencing of T $\beta$ RII, ALK-1, ALK-5, endoglin or T $\beta$ RIII. T $\beta$ RII, ALK-1, ALK-5 and endoglin gene silencing had no effect on constitutive VEGF release 
A
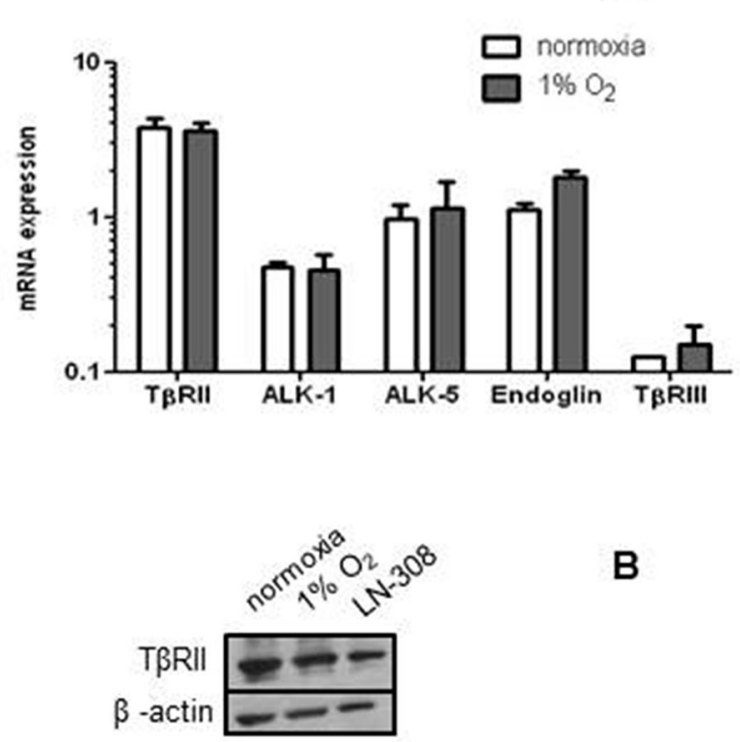

B

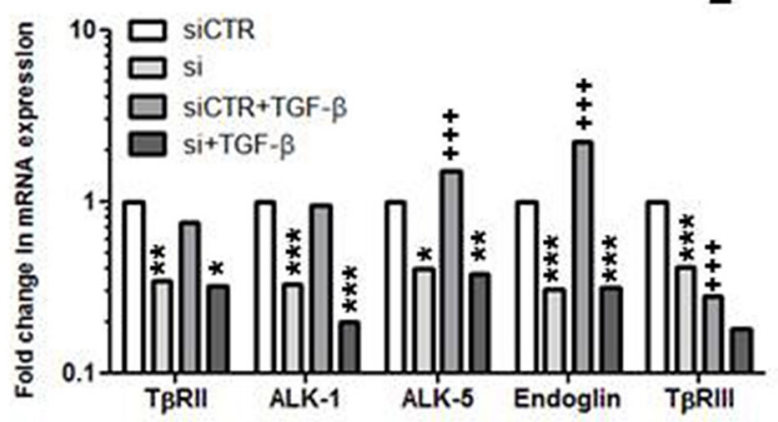

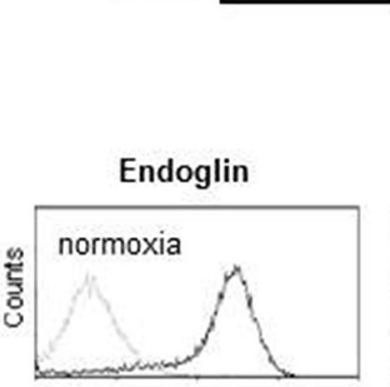

C
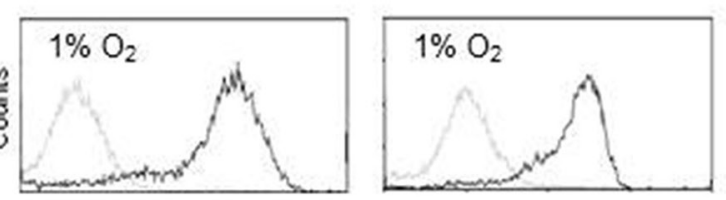

D

\section{T $\beta$ RIII}
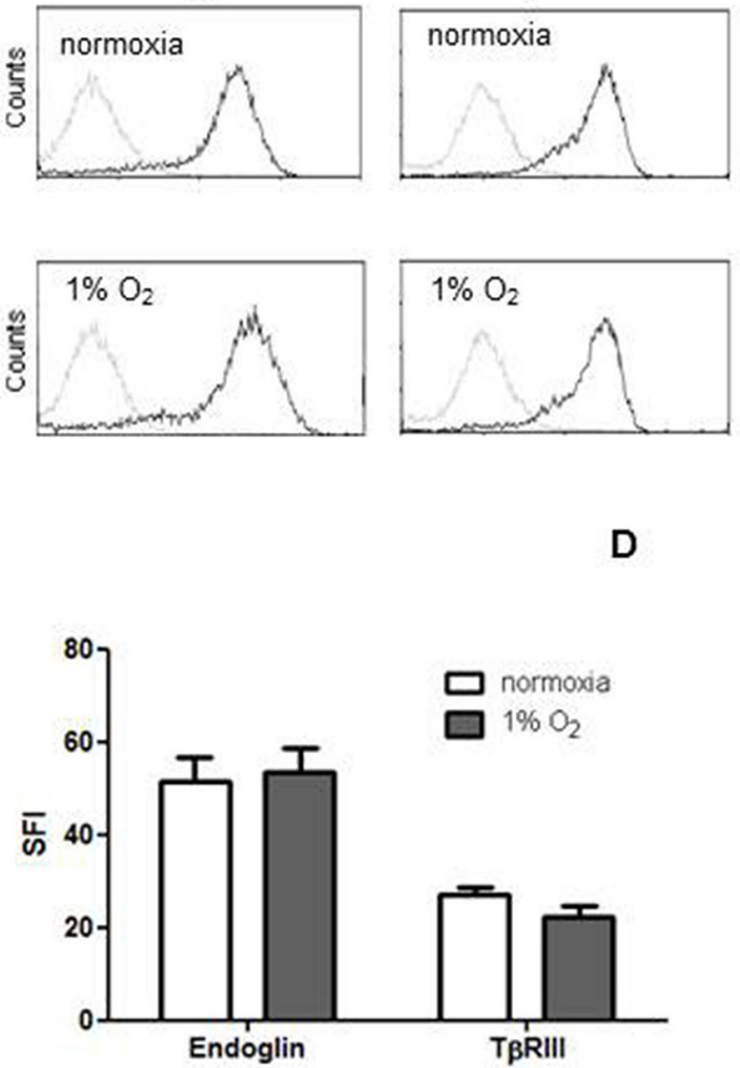

F

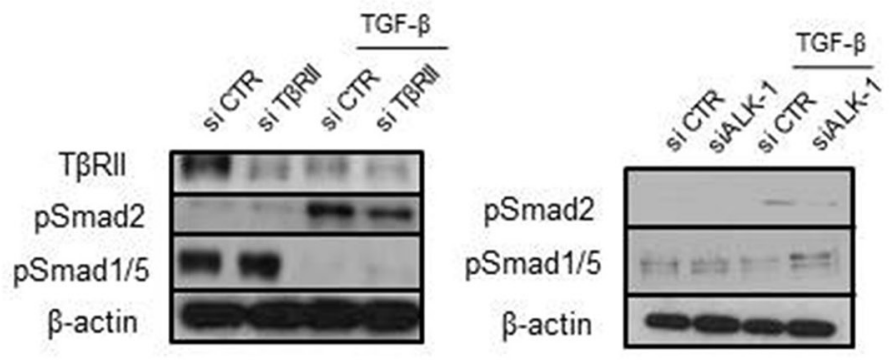

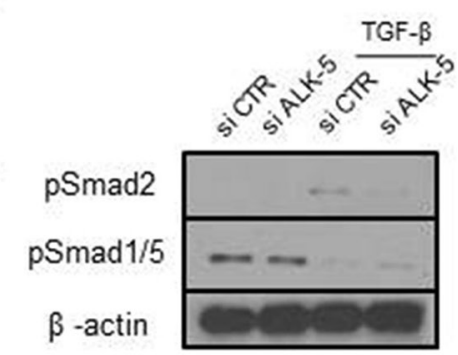
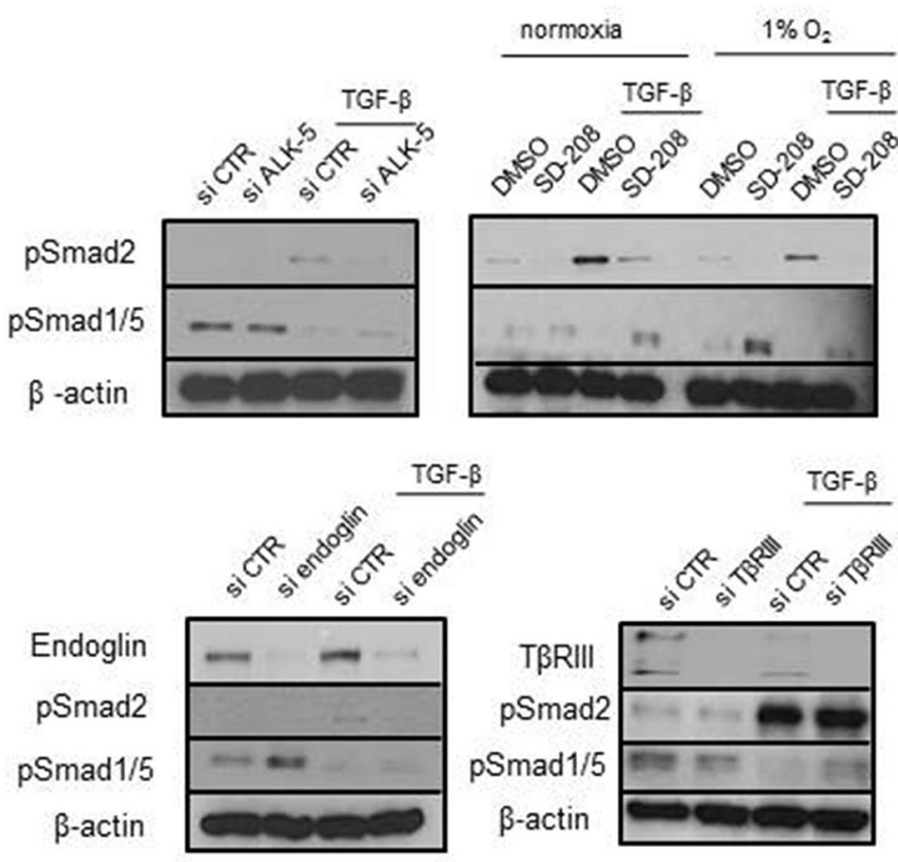

Figure 1: hCMEC express TGF- $\beta$ receptors and coreceptors. A-D. The levels of mRNA for TGF- $\beta$ receptors RII, ALK-1, ALK5 and endoglin or RIII were assessed by RT-PCR (A) and protein by immunoblot (B) or flow cytometry (C, D) as feasible under normoxia and hypoxia. Data in A are expressed as mean values and $\mathrm{SD}(n=4)$. E, $\mathbf{F}$. TGF- $\beta$ receptor gene silencing was verified on $\mathrm{mRNA}(n=3)$ and protein level. In F, the effect of TGF- $\beta$ receptor gene silencing on constitutive and TGF- $\beta$ (10 ng/ml, $72 \mathrm{~h})$-evoked pSmad 2 and $\mathrm{pSmad} 1 / 5$ levels was studied by immunoblot. SD-208 $(1 \mu \mathrm{M}, 72 \mathrm{~h})$ was included to confirm the ALK-5 findings $(n=3)$. $\left({ }^{*} p<0.05, * * p<0.01, * * * p\right.$ $<0.001$, one-way ANOVA followed by Tukey's post hoc test, effect of specific siRNA, ${ }^{+++} p<0.001$, effect of TGF- $\beta$ ). 
A
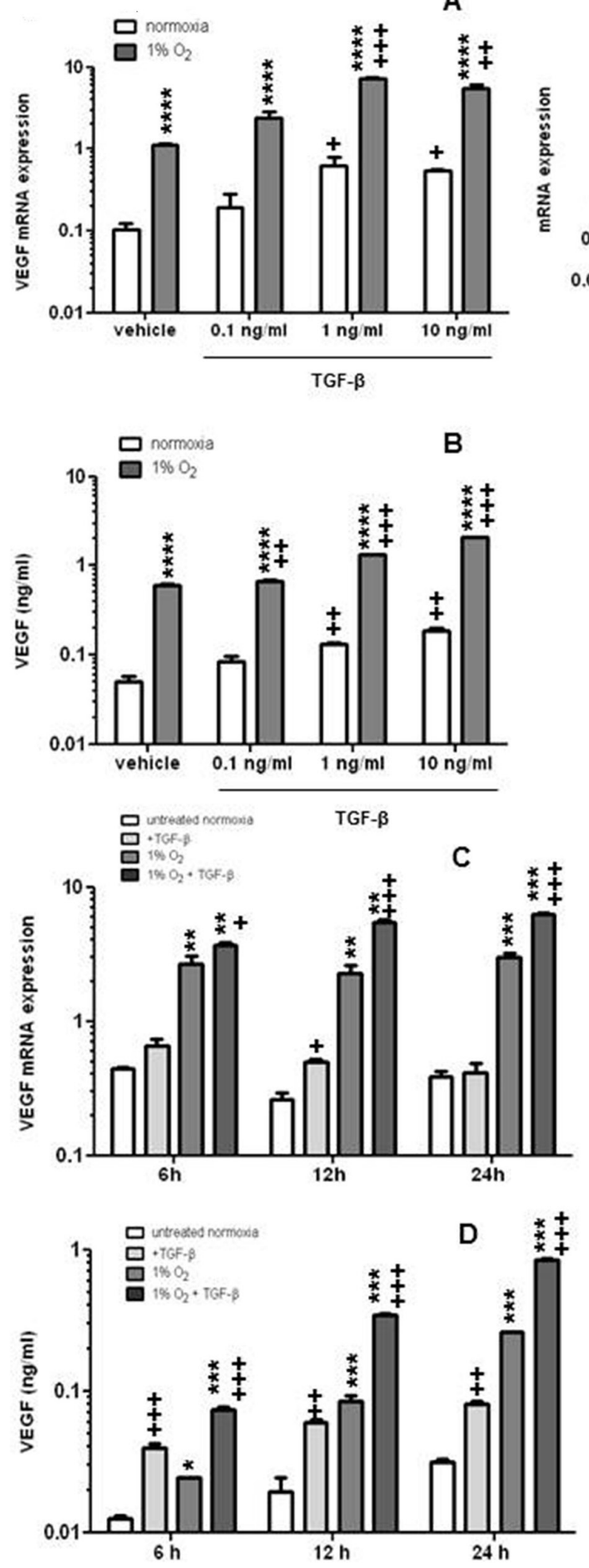

E
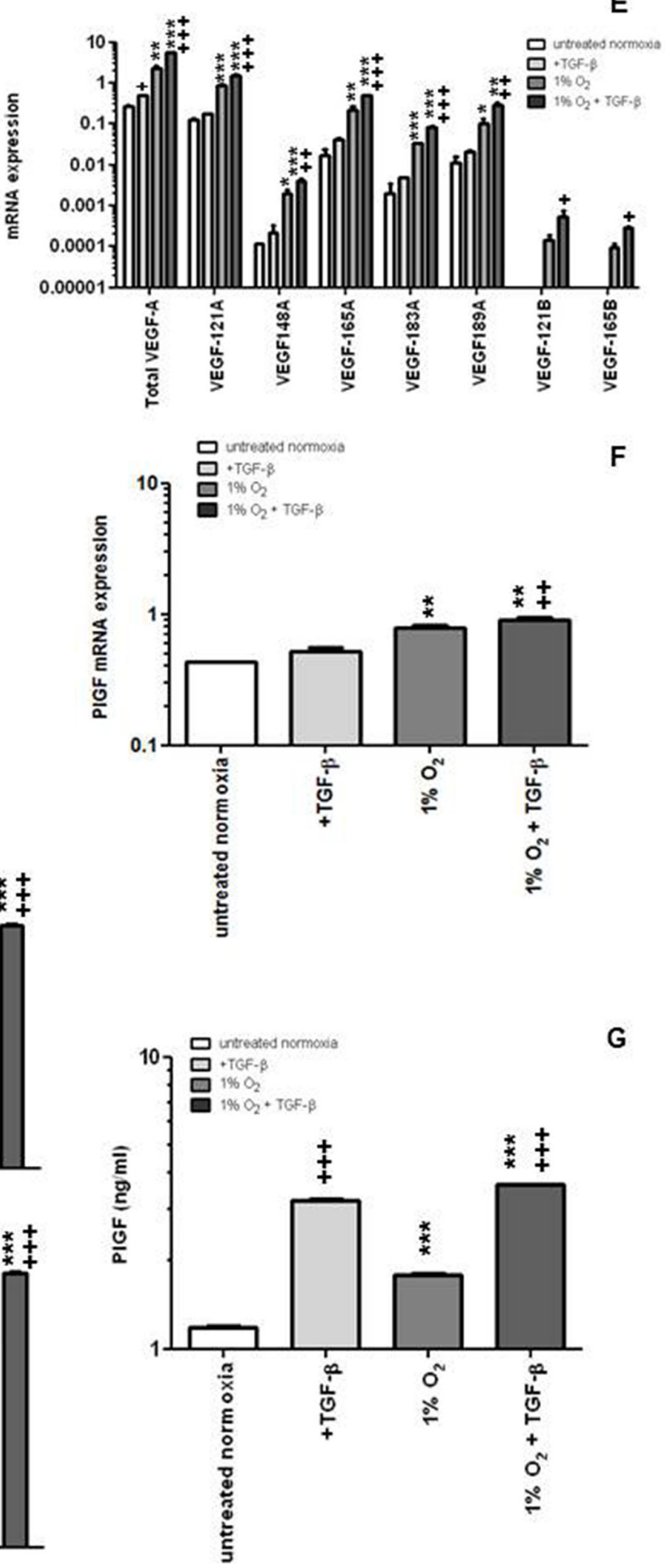

Figure 2: TGF- $\boldsymbol{\beta}$ induces VEGF and PIGF release by endothelial cells. A, B. hCMEC were seeded in full medium, serumstarved for $24 \mathrm{~h}$, and then cultured in the absence or presence of TGF- $\beta$ at the indicated concentrations in normoxia or hypoxia and assessed for VEGF mRNA expression by qRT-PCR at $12 \mathrm{~h}$ (A) or VEGF protein concentrations in the supernatant by ELISA at $24 \mathrm{~h}$ (B) C, D. Similar experiments as in A, B were performed to assess the time dependency of VEGF modulation by TGF- $\beta$. E, F. The expression of VEGF isoforms (E) or PlGF (F) mRNA was investigated by qRT-PCR (VEGFXXXA, proangiogenic isoforms, VEGFXXXB, weakly angiogenic isoforms). G. PIGF concentrations in the supernatant were analyzed by ELISA. Data are expressed as mean and SD $(n=3)$ $\left({ }^{*} p<0.05,{ }^{*} p<0.01,{ }^{* * *} p<0.001,{ }^{* * *} p<0.0001\right.$, one-way ANOVA followed by Tukey's post hoc test, hypoxia versus normoxia, ${ }^{+} p<0.05,{ }^{++} p<0.01,{ }^{+++} p<0.001$, one-way ANOVA followed by Tukey's post hoc test, effect of TGF- $\beta$ ). 
whereas silencing of T $\beta$ RIII reduced VEGF release by 2 -fold. In contrast, when VEGF release was induced by exogenous TGF- $\beta$, silencing of T $\beta$ RII, ALK-5 or T $\beta$ RIII was inhibitory (Figure $3 \mathrm{~A}$ ). Silencing of TGF- $\beta$ receptors did not modulate constitutive PlGF release, however T $\beta$ RII or ALK-5 depletion significantly inhibited TGF- $\beta$ induced PlGF secretion (Figure 3B).

The important signaling function of ALK-5 was confirmed by pharmacological studies using SD-208 which demonstrated no effect on constitutive VEGF release, but strong activity against TGF- $\beta$-evoked VEGF gene transcription and protein release (Figure $3 \mathrm{C}-3 \mathrm{D}$ ). This effect was not restricted to specific VEGF mRNA isoforms (Supplementary Figure 3). Under hypoxic conditions, SD-208 even inhibited constitutive VEGF release. The effects of TGF- $\beta$ and accordingly SD-208 were overall more prominent for PlGF than for VEGF (Figure 3E-3F).

\section{Transcriptional regulation of TGF- $\beta$-evoked VEGF release}

To elucidate the transcriptional regulation of VEGF by TGF- $\beta, 2$ major transcription factors known to have multiple response elements on the promoter region of VEGF, namely, specificity protein (SP1) and early growth response (EGR)1 were screened for basal mRNA expression in hCMEC, HUVEC and two glioma cell lines, U87MG and LN-18 (Supplementary Figure 4A-4B). All cells expressed SP1 and EGR1. SP1 and EGR1 mRNA expression decreased with TGF- $\beta$ exposure at $1-6 \mathrm{~h}$ in hCMEC, however, protein levels were unaffected (Supplementary Figure 4C). Moreover, the silencing of SP1 did not alter VEGF mRNA expression or protein release (Supplementary Figure 4D). Hence, these data do not support the idea that these transcription factors are involved in the TGF- $\beta$-evoked increase of VEGF in hCMEC in normoxia.

\section{TGF- $\beta$ induces endothelial mesenchymal transition (EndMT) and TGF- $\beta$-stimulated supernatant increases tube formation via VEGFR signaling in hCMEC}

We noted that exposure to TGF- $\beta$ caused changes in the morphology of hCMEC, making the cells more elongated and spindle-like in a SD-208-sensitive, thus presumably ALK-5-dependent manner (Figure 4A). Interestingly, however, SD-208 alone induced tube formation, endothelial cell sprouting and expression of the tight junction marker, CLDN5. Conversely, exogenous TGF- $\beta$ blocked the formation of tubes and sprouts and decreased vWF and CLDN5 mRNA expression. Pretreatment with SD-208 rescued tube formation, sprouting, vWF and CLDN5 mRNA expression (Figure 4B-4D). Further, TGF- $\beta$ increased integrin $\beta 3$ and $\beta 5$, snail family zinc finger (SNAI) 1 and N-cadherin mRNA expression and protein levels and pretreatment with SD208 attenuated this increase (Figure 4D-4F). Altogether, the pattern of decreased vWF [4], CLDN5 [5, 6] with a concomitant increase in $\beta 3$ [7] and $\beta 5$ integrin expression [8], SNAI1 [5, 9] and N-cadherin [10] are prominent signs of mesenchymal transition. To dissect the apparent opposing pro- and anti-angiogenic effects of TGF- $\beta$ on hCMEC, we changed the experimental paradigm and isolated the effect of TGF- $\beta$-induced VEGF on tube formation and cell sprouting by using supernatants of hCMEC treated with TGF- $\beta$ for $96 \mathrm{~h}$. These were added to hCMEC that had been pre-treated with vehicle (DMSO) or SD-208. Under these conditions, TGF- $\beta$-stimulated supernatant increased tube formation and sprouting. SD208 super-induced these pro-angiogenic effects of TGF$\beta$-stimulated supernatants, consistent with antagonistic activity of endogenous or supernatant-derived TGF- $\beta$ and illustrating how TGF- $\beta$ and VEGF counterbalance the endothelial phenotype. Cediranib, a pan-VEGFR inhibitor, decreased constitutive and TGF- $\beta$-stimulated supernatantinduced tube formation in the absence or presence of SD208 (Figure 4G).

\section{Endothelial properties of glioblastoma-derived endothelial cells (GMEC)}

Finally we wished to confirm the principle observations summarized above in freshly isolated CD31positive ex vivo endothelial cells (ZHE-459, ZHE-464, ZHE-483-2) from glioblastoma tissue. Their endothelial nature was verified by CD31, CD34, and vWF expression and by their tube formation capacity (Supplementary Figure 5A-5B). CD31 mRNA expression in the CD31positive ZHE-464 cells at P5 was reduced approximately 50 times compared to that on the day of isolation whereas CD31-negative cells did not express CD31 even after 5 passages in endothelial medium, DMEM or neurobasal medium (Supplementary Figure 5C).

\section{Reduction of VEGF receptor levels in hypoxia in hCMEC and GMEC}

The basal expression of VEGFR-1 and VEGFR-2 was determined at mRNA and protein levels at normoxia or after $24 \mathrm{~h}$ of hypoxia in hCMEC and GMEC. VEGFR-1 and VEGFR-2 mRNA expression did not change in hypoxia in hCMEC (Figure 5A). VEGFR-1 protein levels at the cell surface and after permeabilization were not altered (Figure 5B). In contrast, there was a strong decrease in VEGFR-2 protein levels under hypoxia as assessed by immunoblot (Figure 5C). In ZHE-464 the mRNA expression of VEGFR-1 increased, whereas VEGFR-2 was reduced at the mRNA and protein levels in hypoxia (Figure 5D), suggesting differential regulation of the VEGF receptors by hypoxia. 

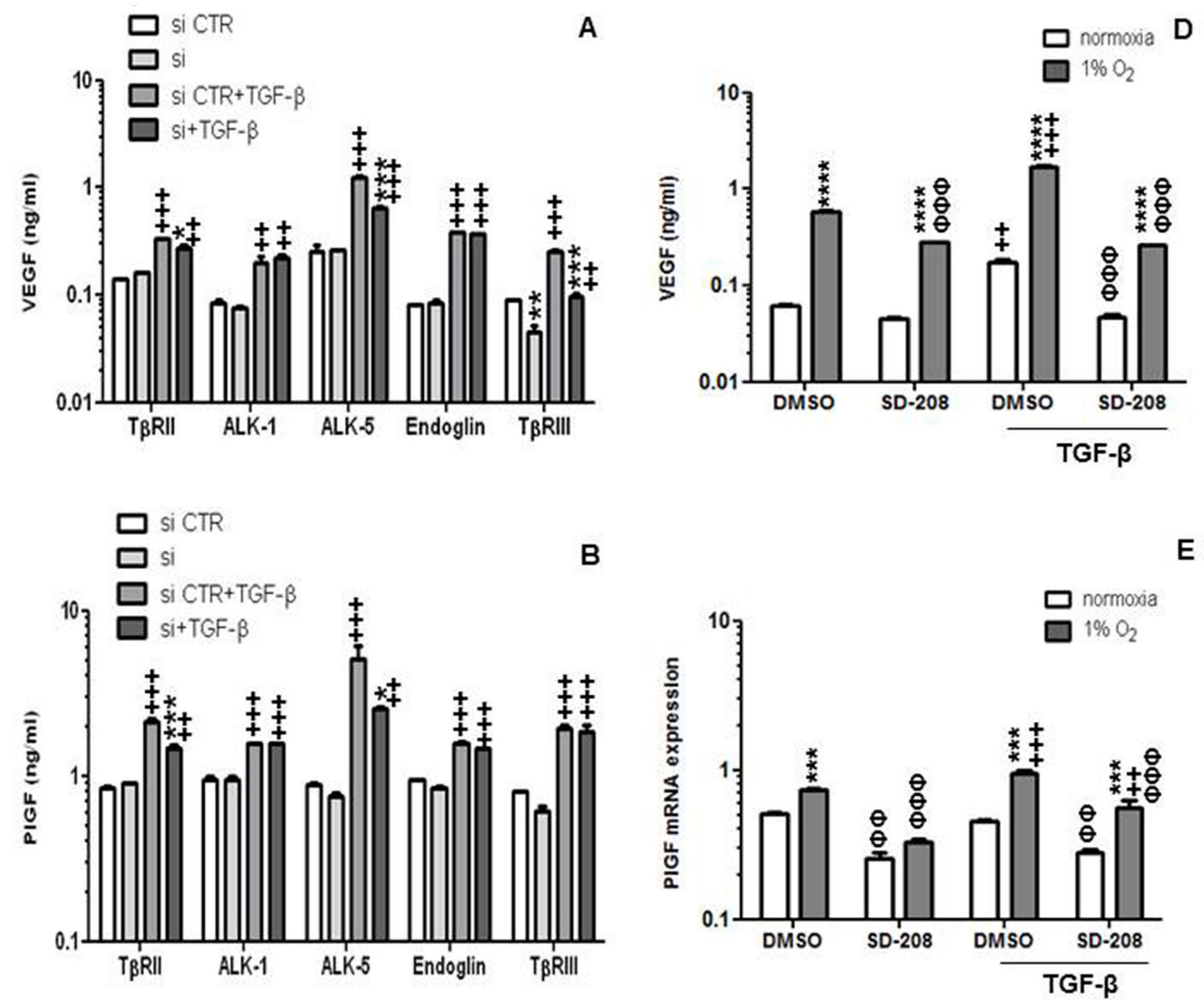

B E
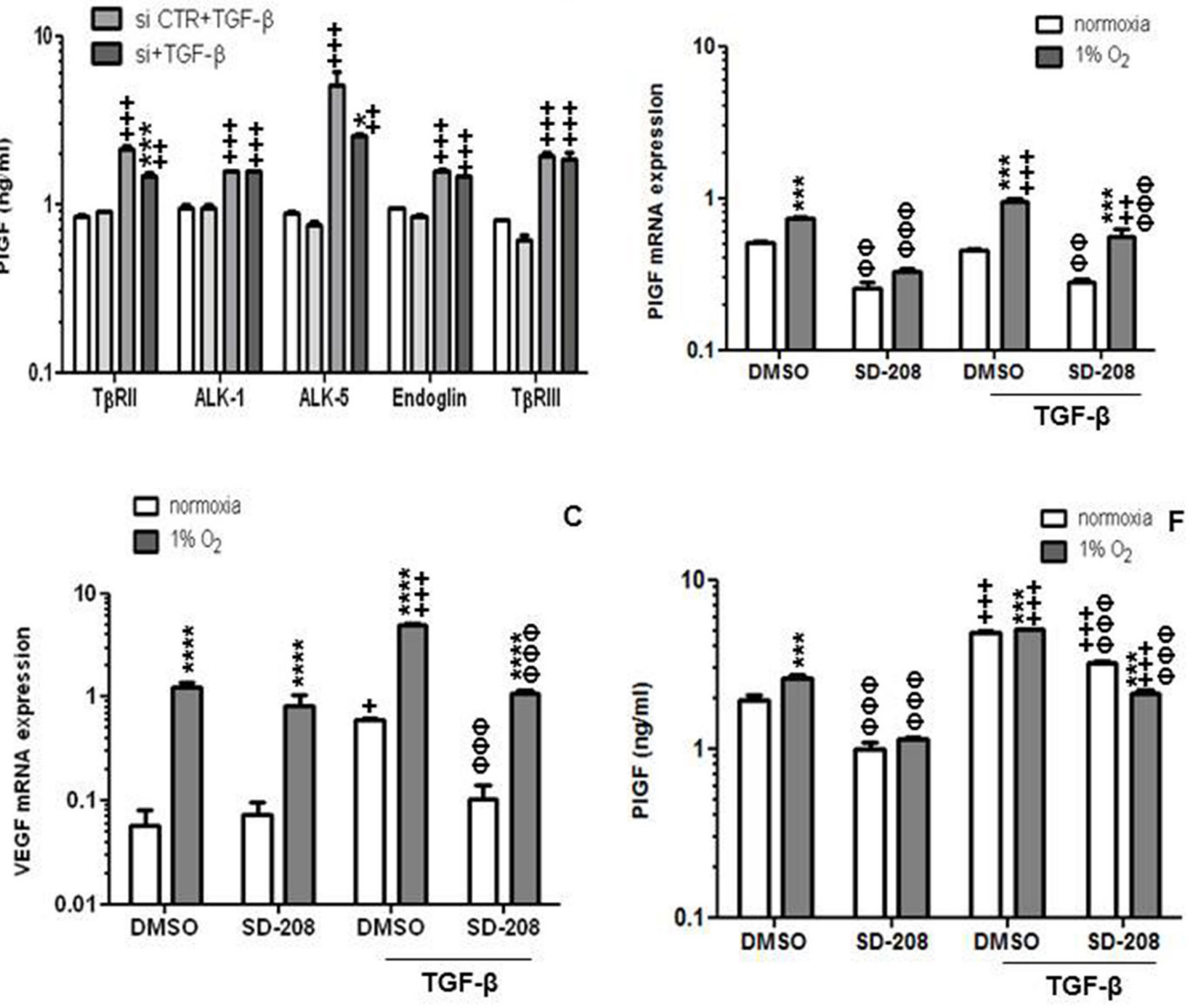

Figure 3: TGF- $\beta$-mediated induction of VEGF in endothelial cells involves RII, ALK-5 and RIII. A. The effect of TGF- $\beta$ receptor gene silencing on constitutive or TGF- $\beta$-evoked VEGF release was assessed by ELISA at $72 \mathrm{~h}(* p<0.05, * * p<0.01, * * * p<$ 0.001 , one way ANOVA followed by Tukey's post hoc test, effect of specific siRNA, ${ }^{+} p<0.05,{ }^{++} p<0.01,{ }^{++} p<0.001$, effect of TGF- $\beta$ ). B. The effect of TGF- $\beta$ receptor gene silencing on constitutive or TGF- $\beta$-evoked PIGF release was assessed by ELISA at $72 \mathrm{~h}\left({ }^{*} p<0.05\right.$, ${ }^{* *} p<0.01,{ }^{* * *} p<0.001$, effect of specific siRNA, ${ }^{+} p<0.01,{ }^{++} p<0.001$, effect of TGF- $\beta$ ). C-F. The modulation of constitutive or TGF$\beta$-evoked VEGF (C, D) or PIGF (E, F) mRNA expression (C, E) or protein release (D, F) by hypoxia or SD-208 or both was determined by RT-PCR or ELISA. Data are expressed as mean and $\mathrm{SD}(n=3) .\left({ }^{*} p<0.05,{ }^{*} p<0.01,{ }^{* * *} p<0.001\right.$, two-way ANOVA, hypoxia versus normoxia, ${ }^{+} p<0.05,{ }^{++} p<0.01,{ }^{++} p<0.001$, one-way ANOVA followed by Tukey's post hoc test, effect of TGF- $\beta, \Phi \Phi \Phi p<0.001$, oneway ANOVA followed by Tukey's post hoc test, effect of SD-208). 


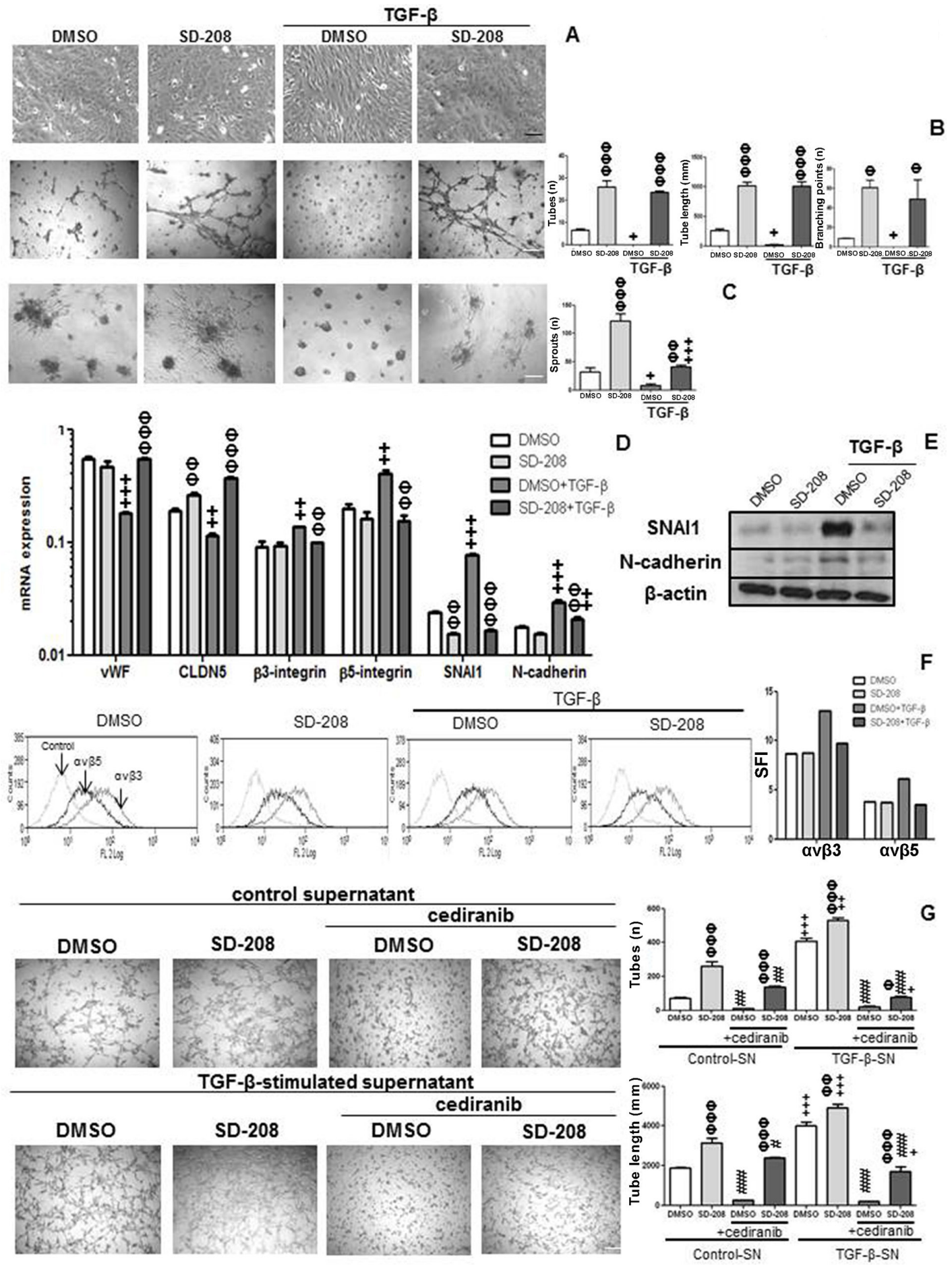

Figure 4: TGF- $\beta$ induces EndMT in hCMEC and TGF- $\beta$-stimulated hCMEC supernatant increases tube formation. A. hCMEC were seeded in full medium, treated with TGF- $\beta(10 \mathrm{ng} / \mathrm{ml})$ or SD-208 $(1 \mu \mathrm{M})$ for $96 \mathrm{~h}$, and examined by phase contrast microscopy. B. Tube formation was quantified by assessing the number of tubes (n), tube length $(\mathrm{mm})$ and number of branching points (n). C. Endothelial cell sprouting was assessed by counting numbers of sprouts (n). D. mRNA expression of vWF, CLDN5, $\beta 3$ and $\beta 5$ integrins, SNAI1 and $\mathrm{N}$-cadherin was assessed by qRT-PCR under the same conditions as in A, for $72 \mathrm{~h}$. Data are expressed as mean and SD $(n=3)\left(^{+} p<0.05\right.$, ${ }^{++} p<0.01,{ }^{++} p<0.001$, one-way ANOVA followed by Tukey's post hoc test, effect of TGF- $\beta, \Phi \Phi p<0.01$, ФФФ $p<0.001$, effect of SD208). E. Protein levels of SNAI1 and N-cadherin were assessed by immunoblot under the same conditions as A at $96 \mathrm{~h}$. F. Protein levels of $\alpha v \beta 3$ and $\alpha v \beta 5$ was assessed by flow cytometry under the same conditions as in A, at $96 \mathrm{~h}$. G. hCMEC supernatant treated with TGF- $\beta$ for $96 \mathrm{~h}$ was concentrated and added with or without cediranib $(1 \mu \mathrm{M})$ to hCMEC pretreated with DMSO or $1 \mu \mathrm{M}$ SD-208 for $1 \mathrm{~h}$. Tube formation was assessed after $12 \mathrm{~h}$, by determining the number of tubes and tube length. Data are expressed as mean and $\mathrm{SD}(n=3)(\Phi \Phi p$ $<0.01$, ФФФ $p<0.001$, one-way ANOVA followed by Tukey's post hoc test, effect of SD-208, ${ }^{+} p<0.05,{ }^{++} p<0.01,{ }^{+++} p<0.001$, effect of TGF- $\beta$-stimulated supernatant, $\# p<0.05$, \#\#\#p<0.001, effect of cediranib). 


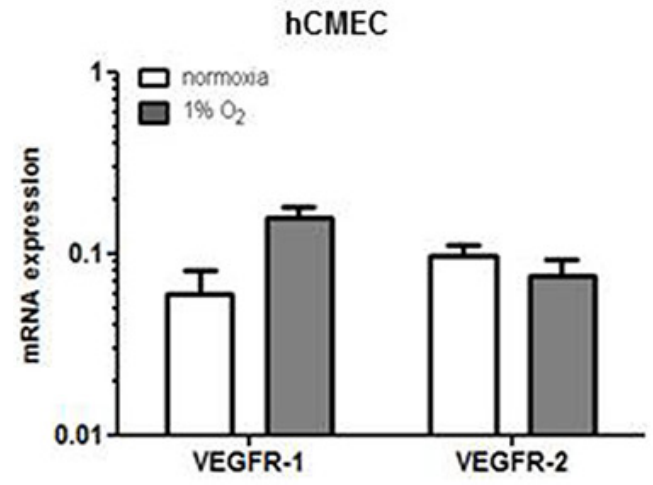

B

VEGFR-1

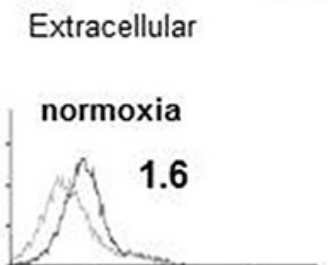

Intracellular
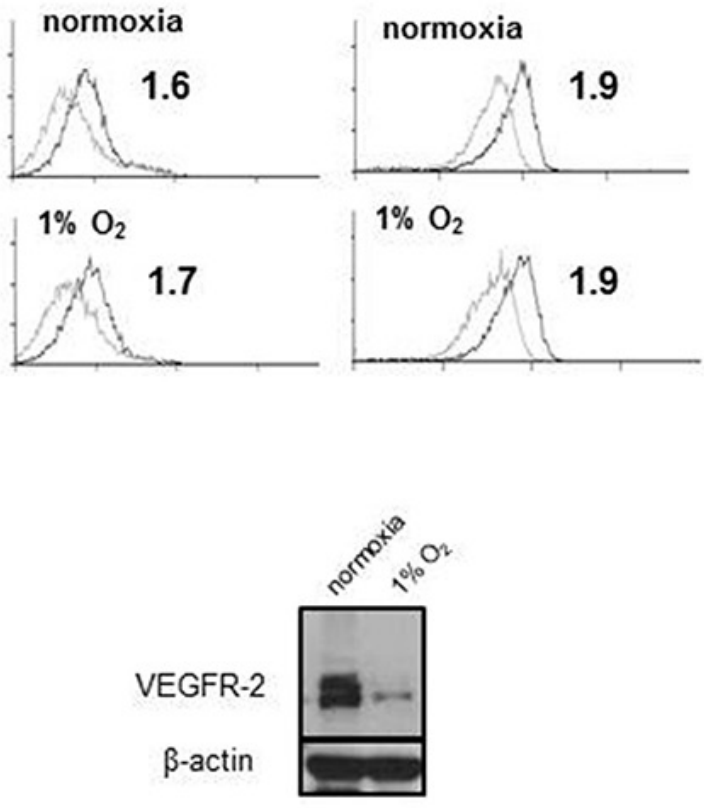

C

D

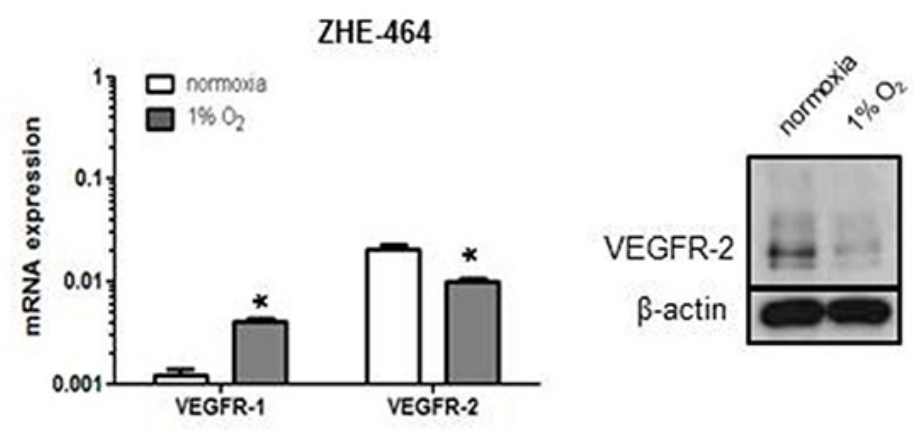

Figure 5: Modulation of VEGFR expression by hypoxia in hCMEC and GMEC. A. VEGFR-1 or VEGFR-2 mRNA expression were assessed under normoxia or $24 \mathrm{~h}$ of hypoxia by qRT-PCR. B. Basal levels of extracellular or intracellular VEGFR-1 protein were assessed by flow cytometry under normoxia or hypoxia, SFI are indicated. C. VEGFR-2 levels of hCMEC were assessed by immunoblot. D. Similar experiments as in A and C were performed in ZHE-464. Data are expressed as mean and SD $(n=3)$. (*, effect of hypoxia, student $t$-test). 


\section{TGF- $\beta$ control of VEGF release in GMEC}

Silencing of ALK-5 in the GMEC was confirmed by RT-PCR (Supplementary Figure 5D). Exogenous TGF- $\beta$ induced pSmad 2 and pSmad1/5 in GMEC, and ALK5 silencing attenuated this effect (Figure 6A). Further, silencing of ALK-5 reduced constitutive VEGF release in ZHE-459 and ZHE-483-2. TGF- $\beta$ increased VEGF in an ALK-5-dependent fashion in ZHE-459, ZHE-464 and ZHE-483-2 (Figure 6B). Similarly, silencing of ALK-5 reduced constitutive and TGF- $\beta$-evoked PIGF release in ZHE-459, ZHE-464 and ZHE-483-2 (Figure 6B).

\section{TGF- $\beta$ induces EndMT and TGF- $\beta$-stimulated supernatant increases tube formation via VEGFR signaling in GMEC}

Tube formation was enhanced by pharmacological inhibition of ALK-5 in ZHE-459, ZHE-464 and ZHE483-2. Conversely, TGF- $\beta$ inhibited tube formation, but pre-treatment with SD-208 rescued tube formation, confirming that TGF- $\beta$ inhibits angiogenic properties via ALK-5 in GMEC, too (Figure 6C). Further, TGF- $\beta$ induced EndMT in ZHE-464 and ZHE-483-2. TGF- $\beta$ reduced the apico-basal polarity of ZHE-464 and created more spindle shaped ZHE-483-2 cells. TGF- $\beta$ decreased vWF and CLDN5 in ZHE-464 and ZHE-483-2, and concomitantly increased SNAI1 and N-cadherin in an ALK-5-dependent manner, very similar to hCMEC (Figure 7A-7B). Similar to hCMEC, cediranib suppressed the constitutive and TGF$\beta$-stimulated supernatant-induced tube formation in the absence or presence of SD-208 in ZHE-459 (Figure 7C).

\section{DISCUSSION}

Angiogenesis is an important step in the multi-step formation of solid cancers including glioblastoma. It requires a crosstalk between tumor and endothelial cells that is likely to involve much more complex interactions than merely hypoxic tumor cell-derived VEGF acting on endothelial cells. Targeting blood vessel formation in glioblastoma has been the favored therapeutic strategy in clinical drug development in the first decade of this century. Yet, the failure of multiple drugs acting not only on VEGF or its receptors, but also on alternative targets including integrins has imposed a brake on further efforts of targeting angiogenesis and instead called for a better understanding of the processes that govern glioblastomaassociated blood vessel formation [11].

Primary resistance to or escape from anti-angiogenic therapy in glioblastoma is likely to be mediated by compensatory activation of multiple pro-angiogenic pathways and shaped by complex interactions between tumor cells and their microenvironment [12]. VEGF remains to be the major molecule thought to drive endothelial cell growth, migration, vessel dilation and permeability. VEGF, VEGF-B, VEGF-C, VEGF-D and PIGF represent a family of related growth factor molecules which bind to VEGFR1-3 with varying affinity. VEGF binding to VEGFR-2 is critically required for vascular development and sprouting, maturation and differentiation of endothelial cells [13].

TGF- $\beta$ is a multifunctional cytokine that has been strongly associated with the malignant phenotype of glioblastoma and become an attractive target for pharmacological intervention $[14,15]$ Here we report that hCMEC express all known TGF- $\beta$ receptors and coreceptors (Figure 1). Their constitutive VEGF release was largely unaffected by TGF- $\beta$ receptor gene silencing except for the effect of T $\beta$ RIII coreceptor silencing (Figure 3A), suggesting that T $\beta$ RIII exerts activity beyond TGF- $\beta$ signaling in this paradigm [16]. Exogenous TGF- $\beta$ induced VEGF mRNA synthesis and protein release in hCMEC in a time- and concentration-dependent manner (Figure 2). The inhibition of VEGF release by ALK-5 gene silencing or pharmacological inhibition using SD208 led to the identification of ALK-5 as the principal type 1 receptor mediating the VEGF induction by TGF- $\beta$ (Figure 3), consistent with the observation that ALK- $5^{-1-}$ mouse endothelial cells obtained from E9.5 embryos shows reduced VEGF mRNA expression [17].

TGF- $\beta$ has been shown to increase PlGF mRNA and protein release in keratinocytes [18] and in retinal epithelium [19]. We show that TGF- $\beta$ induces PlGF expression and release in endothelial cells in normoxic (Figure 2, Figure 3 and Figure 6) and hypoxic conditions (Figure 3). We further show that ALK5 mediates the effects of TGF- $\beta$ on PIGF and that hypoxia may superinduce the PIGF system in the context of glioblastoma.

We observed that VEGFR-2 protein levels in hCMEC and GMEC decreased under hypoxia (Figure 5). Up-regulation of VEGFR-1 and down-regulation of VEGFR-2 at the mRNA and protein levels have been reported previously in HUVEC exposed to hypoxia [20, 21]. The promoter regions of VEGFR-1 that have HIF response elements (HRE) were identified whereas no obvious HRE on the VEGFR-2 promoter region was detected. It was speculated that the regulation of VEGFR-2 in hypoxia was mediated by an unindentified paracrine soluble factor [20] or through post-transcriptional mechanisms [21]. In response to VEGF-A, hypoxic human dermal microvascular endothelial cells (HDMEC) displayed a reduction in VEGFR-2 phosphorylation compared with normoxia, indicating reduced VEGF-Ainduced receptor activation in hypoxia [22].

We find that TGF- $\beta$ induces EndMT in hCMEC and GMEC as determined by a decrease in the expression of the endothelial markers vWF and CLDN5, inhibition of tube formation and an increase in the expression of the mesenchymal markers SNAI1 and N-cadherin in an ALK-5-dependent manner (Figure 4 and Figure 7). TGF$\beta$-induced mesenchymal transition of mouse pancreatic 


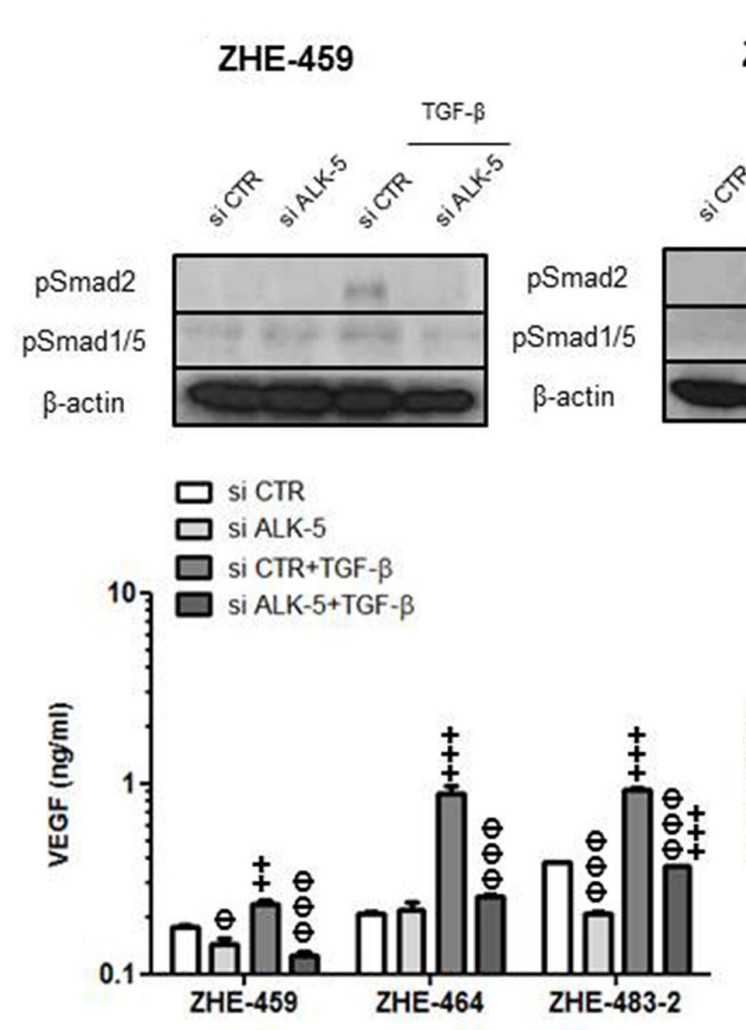

ZHE-464

ZHE-483-2

A
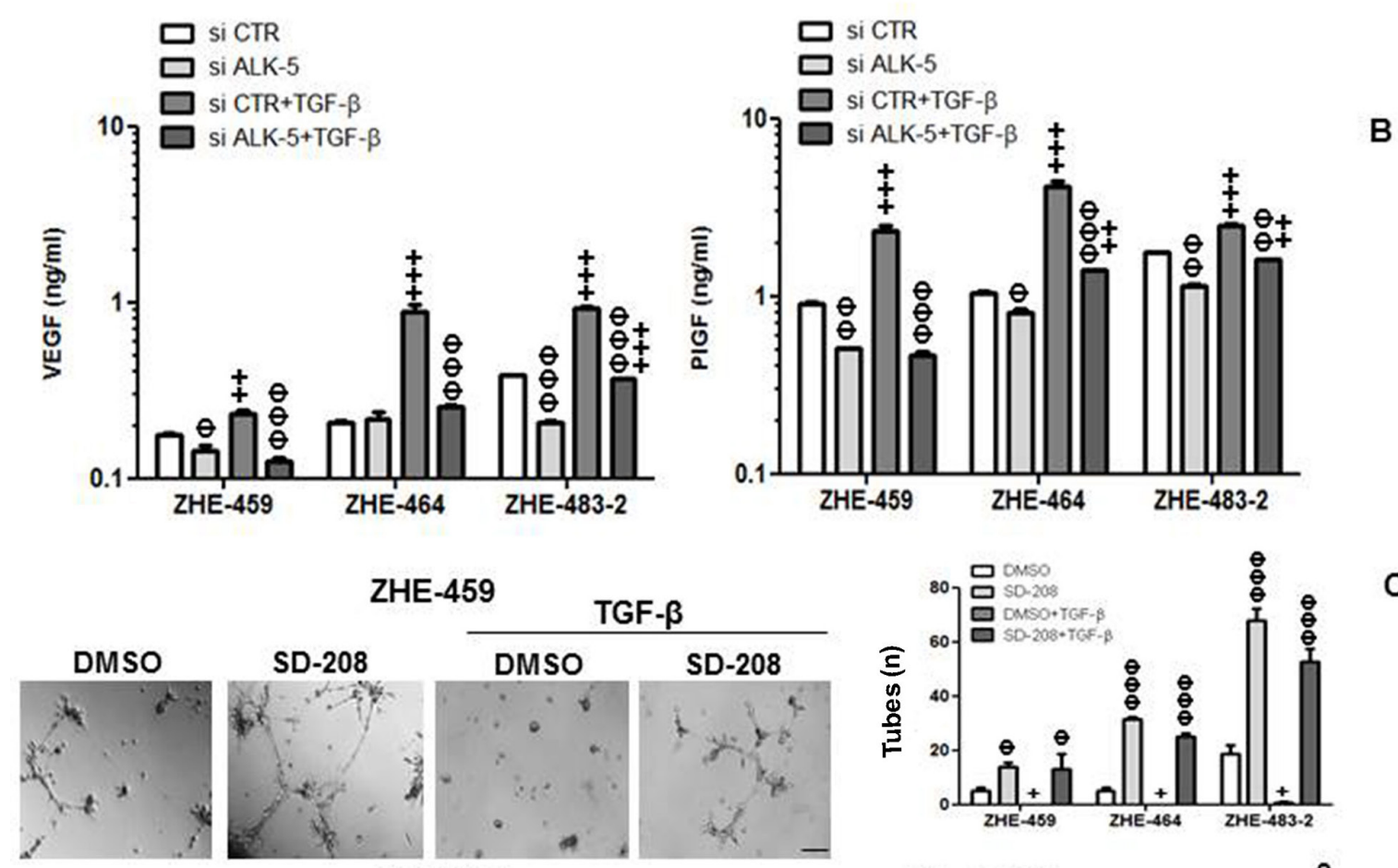

ZHE-464
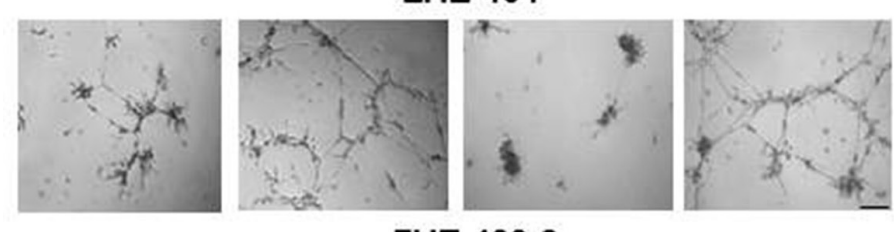

ZHE-483-2
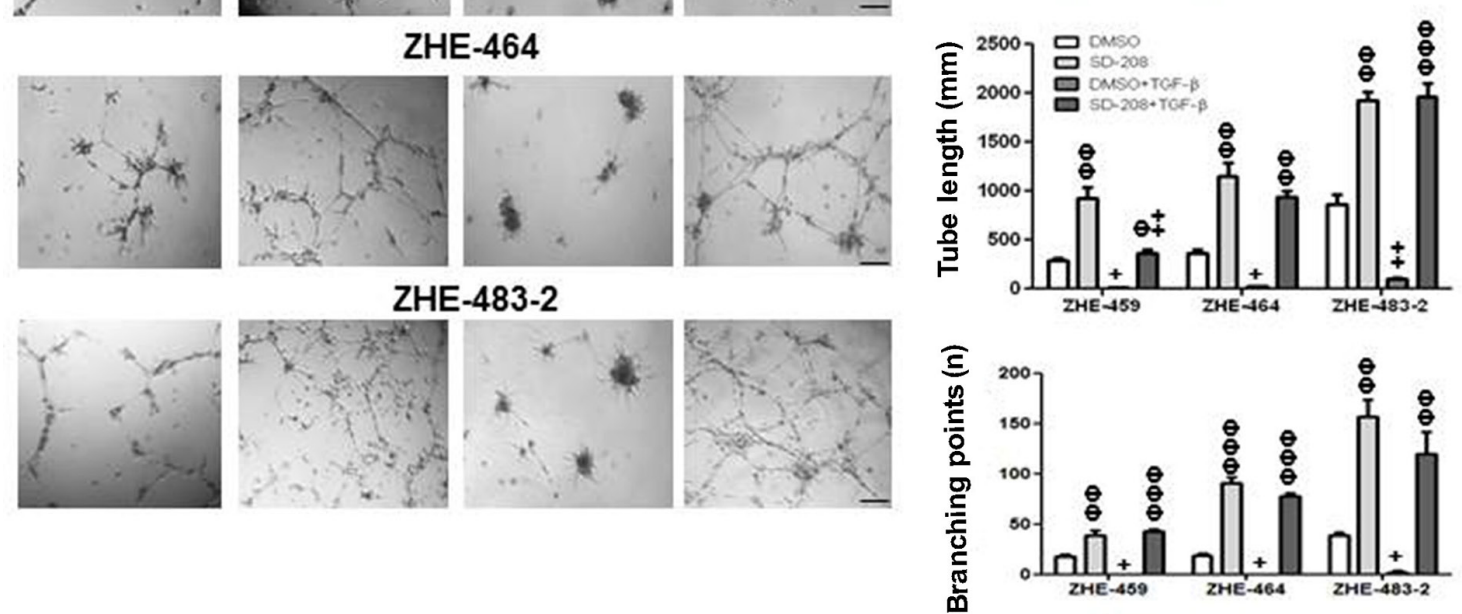

Figure 6: TGF- $\beta$ control of VEGF release in glioblastoma-derived endothelial cells (GMEC). A. The effect of ALK-5 gene silencing on constitutive and TGF- $\beta(10 \mathrm{ng} / \mathrm{ml}, 72 \mathrm{~h})$-evoked $\mathrm{pSmad} 2$ and pSmad1/5 levels was studied by immunoblot. B. The effect of ALK-5 gene silencing on constitutive or TGF- $\beta$-evoked VEGF (left) or PlGF (right) release was assessed by ELISA at $72 \mathrm{~h}$ in ZHE-459,

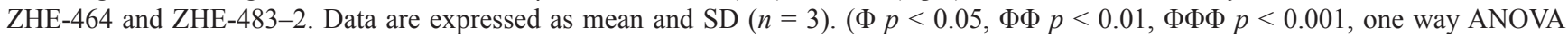
followed by Tukey's post hoc test, effect of si ALK $-5,{ }^{+} p<0.05,{ }^{++} p<0.01,{ }^{+++} p<0.001$, effect of TGF- $\beta$ ). C. ZHE-459, ZHE-464 or ZHE$483-2$ cells were seeded in full medium and treated with TGF- $\beta(10 \mathrm{ng} / \mathrm{ml})$ or SD-208 $(1 \mu \mathrm{M})$ for $96 \mathrm{~h}$. Tube formation was monitored and quantified using number of tubes, tube length and number of branching points as read-outs. Data are expressed as mean and SD $(n=3)$. ( $\Phi$ $p<0.05$, ФФ $p<0.01$, ФФФ $p<0.001$, one way ANOVA followed by Tukey's post hoc test, effect of SD-208, ${ }^{+} p<0.05,{ }^{++} p<0.01,{ }^{+++} p$ $<0.001$, effect of TGF- $\beta$ ). 


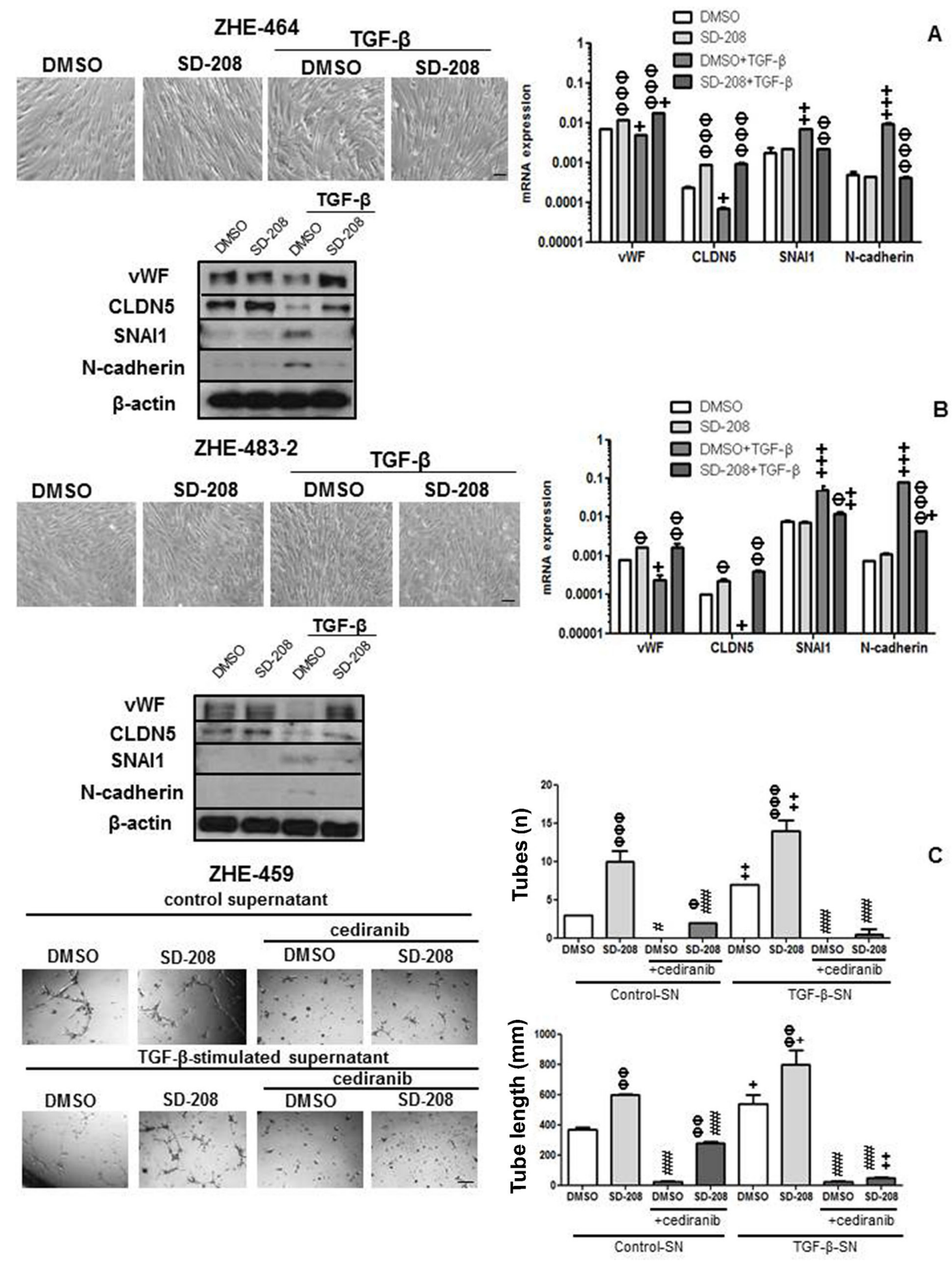

Figure 7: TGF- $\beta$ induces EndMT and TGF- $\beta$-stimulated supernatant increases tube formation in GMEC. A, B. ZHE464 (A) or ZHE-483-2 (B) were seeded in full medium and treated with TGF- $\beta(10 \mathrm{ng} / \mathrm{ml})$ or SD-208 $(1 \mu \mathrm{M})$ for $96 \mathrm{~h}$. Phase contrast images are shown. mRNA expression and protein levels of vWF, CLDN5, SNAI1 and N-cadherin were assessed by qRT-PCR at $72 \mathrm{~h}$ and immunoblot at $96 \mathrm{~h}$ respectively under the same conditions. Data are expressed as mean and $\mathrm{SD}(n=3)(\Phi p<0.05, \Phi \Phi p<0.01, \Phi \Phi \Phi$ $p<0.001$, one way ANOVA followed by Tukey's post hoc test, effect of SD-208, ${ }^{+} p<0.05,{ }^{++} p<0.01,{ }^{++} p<0.001$, effect of TGF- $\beta$ ). C. ZHE-459 supernatant treated with TGF- $\beta$ for $96 \mathrm{~h}$ was concentrated and added with or without cediranib $(1 \mu \mathrm{M})$ to ZHE-459 pretreated with DMSO or $1 \mu \mathrm{M}$ SD-208 for $1 \mathrm{~h}$. Tube formation was assessed after $12 \mathrm{~h}$, by calculating the number of tubes and tube length. Data are expressed as mean and $\mathrm{SD}(n=3)\left(\Phi \Phi p<0.01, \Phi \Phi \Phi p<0.001\right.$, one-way ANOVA followed by Tukey's post hoc test, effect of SD-208, ${ }^{+} p$

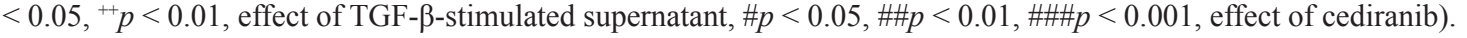


microvascular endothelial cells required Smad-dependent cooperative activation of Rho signals and MRTF-A [23]. TGF- $\beta$ promoted SNAI1-mediated EndMT through convergence of Smad-dependent and Smad-independent signalling in human cutaneous microvascular endothelial cells [24]. Sustained elevation of SNAI1 has been suggested to promote a glial-mesenchymal transition in gliomas after radiation [25].

VEGF and TGF- $\beta$ signalling may induce a plethora of gene expression changes observed in glioblastoma vessels in vivo [26]. The dual effects of TGF- $\beta$ on biological aspects of angiogenesis characterized here (Figure 8) makes the consequences of therapeutic targeting of either pathway difficult to predict. It must be acknowledged that therapeutic targeting of VEGF receptors by cediranib has failed in glioblastoma [27] whereas bevacizumab, while convincingly delaying disease progression, also did not impact overall survival $[28,29]$. Yet, it has remained uncertain to what extent these drugs truly reached their desired site of action which must include the tumor microenvironment. Blood brain barrier permeability may have limited the efficacy of cediranib and bevacizumab would a priori only be able to scavenge humoral VEGF, but probably not be able to prevent autocrine signaling that is likely to be relevant in glioblastoma, too [30]. Accordingly, control of VEGF synthesis and release is still a valid target in glioblastoma.

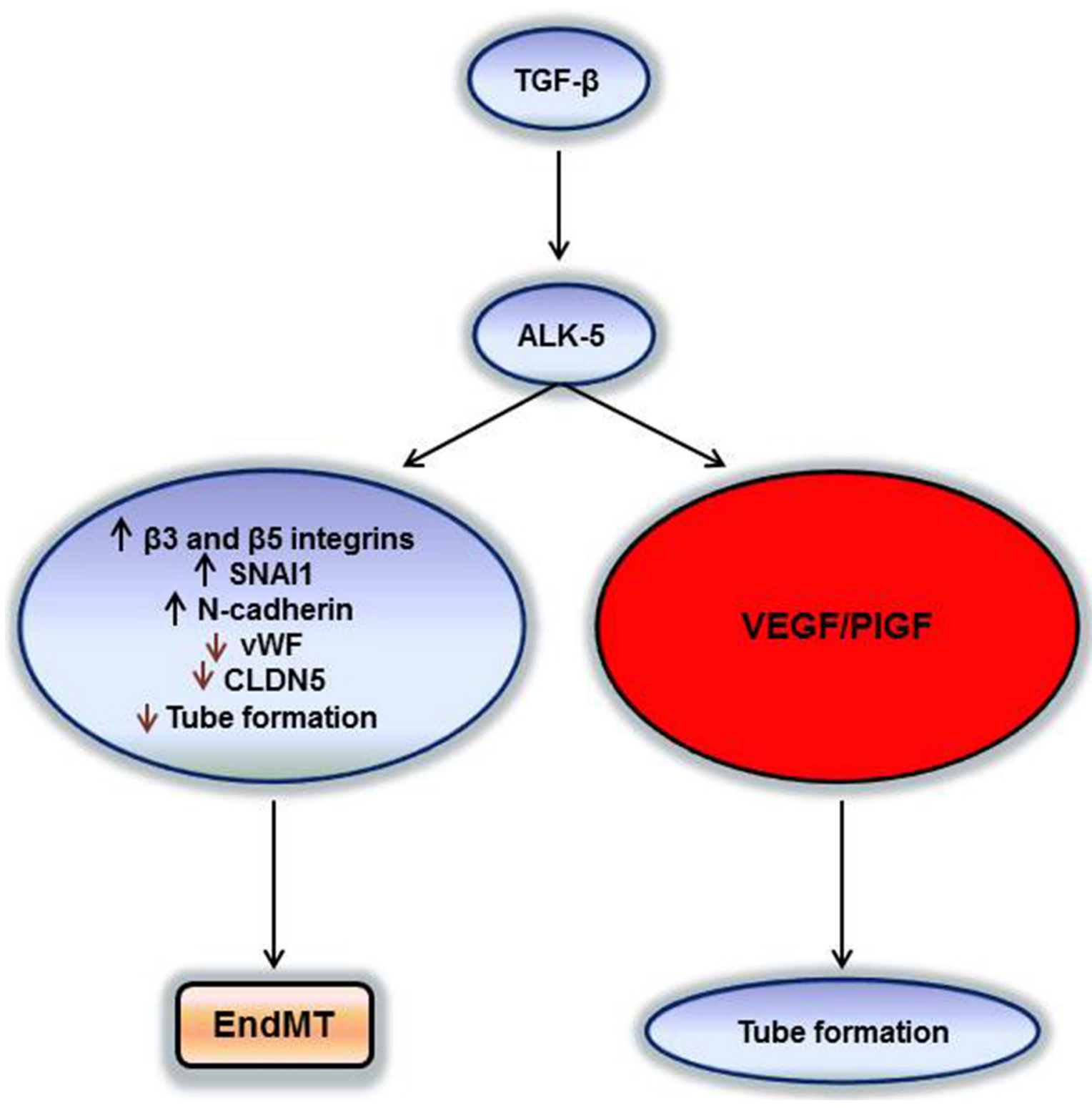

Figure 8: Two pathways of TGF- $\beta / A L K-5$ signalling in hCMEC and GMEC. TGF- $\beta$ can increase VEGF/PIGF secretion via the ALK-5 pathway and create a pro-angiogenic milieu for the tumor or induce EndMT by decreasing endothelial properties and increasing the mesenchymal signatures for the tumor to become potentially more invasive. 


\section{MATERIALS AND METHODS}

\section{Reagents}

Recombinant human TGF- $\beta$, was purchased from R\&D Systems (Minneapolis, MN, USA). All experiments reported herein involving exogenous supplementation were performed with human TGF- $\beta_{2}$. Selected experiments were confirmed using human TGF- $\beta_{1}$ (data not shown). SD-208 [14], a TGF- $\beta$ RI kinase inhibitor was provided by Scios (Fremont, CA, USA). Cediranib (AZD2171) was purchased from Biovision (Milpitas, CA, USA).

\section{Cell culture}

Human cerebral microvascular endothelial cells (hCMEC/D3), kindly provided by P.C. Couraud (Paris, France), human glioblastoma-derived endothelial cells ZHE-459, ZHE-464 and ZHE-483-2 and human umbilical vein endothelial cells (HUVEC) were cultured in Lonza $\mathrm{EBM}^{\mathrm{TM}}$-2 medium (CC-3156, Lonza, Walkersville, MD, USA) with supplements (EGM-2-CC4176) that include $0.5 \mathrm{ml}$ human recombinant epidermal growth factor (hEGF, CC-4317A), $0.2 \mathrm{ml}$ hydrocortisone (CC-4112A), 2 $\mathrm{ml}$ human fibroblast growth factor-B (hFGF, CC-4113A), $0.5 \mathrm{ml}$ VEGF (CC-4114A), $0.5 \mathrm{ml}$ recombinant longinsulin like growth factor ( $\left.\mathrm{R}^{3}-\mathrm{IGF}-1, \mathrm{CC}-4115 \mathrm{~A}\right), 0.5 \mathrm{ml}$ ascorbic acid (CC-4116A), $0.5 \mathrm{ml}$ heparin (CC-4396A), $0.5 \mathrm{ml}$ gentamicin sulphate amphotericin B (GA-1000, CC-4381A), $10 \mathrm{ml}(2 \%)$ fetal bovine serum (FBS, CC4101A) and $5 \mathrm{ml}(1 \mathrm{M})$ HEPES (Gibco, GrandIsland, NY, USA) and $5 \mathrm{ml} \mathrm{CD} \mathrm{lipid} \mathrm{concentrate} \mathrm{(Gibco).}$ hCMEC/D3 were cultured from P30-P37 on Corning ${ }^{\circledR}$ BioCoat ${ }^{\mathrm{TM}}$ collagen type I cellware (Corning) and used for experiments. HUVEC, ZHE-459, ZHE-464 and ZHE483-2 cells were cultured from P2-P7 on the same dishes as hCMEC/D3. All cells were grown in a humidified $37^{\circ} \mathrm{C}$ incubator with $5 \% \mathrm{CO}_{2}$. All starvation experiments for endothelial cells were performed with plain Lonza $\mathrm{EBM}^{\mathrm{TM}}$ 2 medium without any supplements. LN-308, a longterm adherent glioma cell line, was cultured in Dulbecco's modified eagle's medium (DMEM) containing 10\% fetal calf serum (FCS) and 1\% glutamine (Gibco). For all experiments LN-308 cells were starved for $24 \mathrm{~h}$ in DMEM containing $1 \%$ glutamine.

\section{Isolation of human glioblastoma-derived endothelial cells}

The net weight of the glioma tissue was measured followed by dissociation with $10 \mathrm{mg} / \mathrm{ml}$ collagenase/ dispase (11097113001, Roche, Basel, Switzerland) and rotation with gentleMACS C-tubes (130-093-237, Miltenyi biotech, Cologne, Germany). Erythrocytes were lysed by resuspending and incubating the cells in a 3:1 ratio of water:PBS. Cells were then counted and $20 \mu \mathrm{l}$ of FcR blocking reagent and $20 \mu \mathrm{l}$ of CD31 microbeads
(130-091-935, Miltenyi biotech) were added per $10^{7}$ cells. After $15 \mathrm{~min}$ rotating incubation at $4^{\circ} \mathrm{C}$, the cells were passed through a $40 \mu \mathrm{m}$ cell strainer to remove cell aggregates. Cells were then passed through an LS column placed in a magnetic field of a MACS separator. The cells that pass through (CD31-negative population) were again passed through another LS column to get a purer CD31-negative population. These cells were divided into 3 fractions and grown in Neurobasal medium (NBM) supplemented with B-27 $(20 \mu \mathrm{l} / \mathrm{ml})$ and Glutamax $(10 \mu \mathrm{l} /$ ml) (Invitrogen, Carlsbad, CA, USA), FGF and EGF (20 ng/ml each; Peprotech, Rocky Hill, PA, USA), DMEM supplemented with 10\% FCS and 1\% L-glutamine (Gibco) or endothelial medium (EM). The CD31-positive cells which remained in the column were forcefully washed out and cultured in collagen type I-coated dishes until confluency and passaged once more before use. For ZHE-483-2, CD45-positive cells were depleted using LD columns (130-042-901, Miltenyi biotech), and then from the CD45-negative population, CD31-positive cells were isolated using the above procedure.

\section{Real-time (RT) PCR}

Total RNA was prepared with the NucleoSpin System (Macherey-Nagel, Düren, Germany) and cDNA was transcribed using Superscript II reverse transcriptase (Bio-rad, Munich, Germany). For real-time PCR, cDNA amplification was monitored using SYBR Green chemistry on the 7300 Real time PCR System (Applied Biosystems, Zug, Switzerland). The conditions for these PCR reactions were: 40 cycles, $95^{\circ} \mathrm{C} / 15 \mathrm{sec}, 60^{\circ} \mathrm{C} / 1 \mathrm{~min}$, using the primers specified in Supplementary Table 1. Arf1 transcript levels were used as a reference for relative quantification of mRNA expression levels using the $\Delta \mathrm{CT}$ method because they were observed to be stable within each cell line under the experimental conditions reported here.

\section{Immunoblot}

RIPA buffer ( $\mathrm{pH} 7.8$ ) consisting of $1 \% \mathrm{~V} / \mathrm{V}$ NP-40, $5 \%$ sodium deoxycholate $(0.5 \% \mathrm{~V} / \mathrm{V})$ (Sigma Aldrich, Buchs, Switzerland), $1 \mathrm{M}$ Tris/HCl pH 8.0 (Merck KGaA, Darmstadt, Germany), $5 \mathrm{M} \mathrm{NaCl}$ (Merck KGaA), $0.5 \mathrm{M}$ EDTA, pH 8.0 (Sigma) and MilliQ $\mathrm{H}_{2} \mathrm{O}$ was prepared, sterile-filtered and stored at $4{ }^{\circ} \mathrm{C}$. Phosphatase inhibitor cocktail (Sigma), protease inhibitor cocktail sets III and IV (Sigma), $200 \mathrm{mM}$ sodium orthovanadate $(\mathrm{pH} 10)$ and $0.5 \mathrm{M}$ sodium fluoride were added freshly to the RIPA buffer before lysing the cells. After this, protein levels were determined using a Bradford-based protein assay (Biorad). Denatured whole protein lysates $(40 \mu \mathrm{g} /$ lane) were separated on 10-15\% acrylamide gels. After transfer to nitrocellulose (Biorad), blots were blocked in TBST containing 5\% skim milk and incubated overnight at $4^{\circ} \mathrm{C}$ with primary antibodies. Rabbit anti- 
human T $\beta$ RII (1:1000) ((C-16)-R, sc220-R, Santa Cruz Biotechnology, Santa Cruz, CA, USA), rabbit anti-CD105 (1:3000) (ab137389, abcam, Cambridge, UK), goat antiT $\beta$ RIII (1:2000) (AF-242-PB, R\&D Systems), rabbit anti-VEGFR-2 (1:1000) (Cell Signaling, Danvers, MA), rabbit anti-pSmad2 (1:1000) (3108S, Cell Signaling), rabbit anti- Smad2 (1:1000) (3122S, Cell Signaling), rabbit anti-Smad1 (1:1000) (9743S, Cell Signaling), rabbit anti-Smad5 (1:1000) (9517S, Cell Signaling), rabbit antipSmad1/5 (1:1000) (9516S, Cell Signaling), rabbit antivWF (1:1000) (sc-14014, Santa Cruz Biotechnology), rabbit anti-CLDN5 (1:1000) (ABT45, Millipore, Billerica, MA, USA), rabbit anti-Snail (1:1000) (3879S, Cell Signaling), mouse anti-N-cadherin (1:2500) (05-915, Millipore), rabbit anti-SP1 (1:1000) (07-645, Millipore), rabbit anti-EGR-1 (1:1000) (sc-110, Santa Cruz Biotechnology) or goat anti-actin (1:500) (sc 1616, Santa Cruz Biotechnology) were used as primary antibodies. The membranes were then washed in TBST and incubated for $1 \mathrm{~h}$ at room temperature with HRP-coupled goat antirabbit (1:5000) (Santa Cruz Biotechnology) or donkey anti-goat (1:5000) (Santa Cruz Biotechnology) secondary antibodies. Protein bands were visualized by enhanced chemo luminescence (Pierce/Thermo Fisher, Madison, WI, USA).

\section{ELISA}

hCMEC or GMEC were seeded at $2.6 \times 10^{4}$ cells/ $\mathrm{cm}^{2}$. Indicated treatments were performed in basal medium without serum and supplements for indicated time periods. Supernatants were harvested and cellular debris was removed by centrifugation $1200 \mathrm{rpm}$ for $10 \mathrm{~min}$. Supernatants were then concentrated by centrifugation at $4000 \mathrm{~g}$ for 30 min using the Amicon ${ }^{\circledR}$ Ultra 3K device 3,000 NMWL (Millipore). Protein concentrations in supernatants were measured by BCA assay (Pierce Biotechnology, Rockford, IL, USA) and equal amounts of protein were used for VEGF-A ELISA (BMS277/2TEN, eBioscience, Vienna, Austria) and PlGF ELISA (RAB0404, Sigma). Pure serum-free medium without cells was used as a negative control for all ELISA.

\section{RNA interference}

To silence T $\beta$ RII, ALK-1, ALK-5, endoglin or SP1, hCMEC cells were transiently transfected using Metafectene Pro transfection reagent (Biontex, San Diego, CA, USA) and siRNA pools (100 nM), containing four selected siRNA duplexes, each with a modification pattern that eliminates off-target effects caused by both strands (ON-TARGETplus, SMARTpool, (TßRII-L-003930-00, ALK-1- L-005302-02, ALK-5L-003929-00, endoglin-L-011026-00, SP1-026959-00) Dharmacon, Lafayette, CO, SA, USA). ON-TARGETplus non-targeting pool siRNA (Dharmacon) was used as a negative control. For T $\beta$ RIII, three selected siRNA duplexes (S100049595, S100049602, S10049609) were used along with a control non-targeting siRNA pool from Qiagen (Hilden, Germany) with the same transfection reagents and siRNA concentration as used for the silencing of other receptors. Gene silencing was verified by qPCR and immunoblot as indicated.

\section{Angiogenesis-related in vitro assays}

hCMEC were cultured in full medium with TGF- $\beta$ or SD-208 or both for $96 \mathrm{~h}$ before being detached using accutase (PAA Laboratories, Cölbe, Germany) and transferred to growth factor-reduced matrigel (356230, BD Biosciences, Franklin Lakes, NJ, USA) in 96 well plates at 15,000 cells $/ 50 \mu \mathrm{l}$. Tube formation was assessed at 4, 12 and $24 \mathrm{~h}$ and photographs were taken using a Carl Zeiss microscope (Axiovert 100, Göttingen, Germany). Tube length (mm), number of tubes (n) and number of branching points (n) were calculated as average of 3 images per condition from independent experiments using the Adobe Acrobat X Pro (Adobe, Ireland).

For the sprouting assay, the conditions were same as for tube formation except that 2, 000 cells $/ 50 \mu$ were transferred to 96 well plates containing growth factorreduced matrigel and were left in the matrigel for 7 days. Then the number of sprouts formed by the cells was counted for 3 images per condition from independent experiments using ImageJ $1.40 \mathrm{~g}$ software (NIH).

\section{Flow cytometry, cell cycle, and viability assays}

hCMEC were cultured in full medium followed by serum starvation for $24 \mathrm{~h}$ in normoxia or hypoxia. The cells were then detached using accutase (PAA Laboratories), stained with goat anti-VEGFR-1/Flt-1 (AF321, R\&D Systems), mouse anti- $\alpha$ v33 (clone LM609, MAB1976) and mouse anti- $\alpha \mathrm{v} \beta 5$ (clone P1F6, MAB1961) (Merck, Darmstadt, Germany) or appropriate isotype controls: goat IgG, (sc-2028, Santa Cruz Biotechnology) or mouse $\mathrm{IgG}_{2 \mathrm{a}} \mathrm{K}$ (550339, BD Biosciences). After 2 washing steps with PBS containing $0.5 \%$ bovine serum albumin (BSA), cells were incubated at $4{ }^{\circ} \mathrm{C}$ with the following secondary antibodies: anti-human alexa fluor 488 antibody (Invitrogen), anti-goat IgG-FITC (F2016, Sigma Aldrich) or anti-mouse IgG1-PE (RMG1-1, Biolegend, London, UK). For the detection of endoglin, mouse PE anti-human CD105 antibody (323205, Biolegend) or the isotype control PE mouse IgG1K (400113, Biolegend) and for T $\beta$ RIII, goat PE anti-human T $\beta$ RIII (FAB242P, R\&D Systems) or the isotype control PE goat IgG (403004, Biolegend) were used. Subsequently, the cells were washed twice with PBS containing $0.5 \%$ BSA and subjected to flow cytometric analysis. A Cyan ${ }^{\circledR}$ Dako flow cytometer was used and data were analyzed via Summit ${ }^{\circledR}$ software version 4.3 (Beckmann Coulter, Krefeld, Germany). Signal intensity was calculated as the ratio of the mean fluorescence of the specific antibody and the 
isotype control antibody (specific fluorescence index, SFI). A SFI of 1.3 was arbitrarily defined as a significant surface expression. For some analyses, cells were permeabilized by Fix/Perm Buffer Set (Biolegend).

For analysis of cell death, cells were grown in 6-well plates and treated with TGF- $\beta$ (10 ng/ml) for $72 \mathrm{~h}$. Cells were then harvested, annexin (Anx) V-fluorescein isothiocyanate $(1: 100)$ and propidium iodide (PI; $50 \mu \mathrm{g}$ ) $\mathrm{ml}$ ) were added, and fluorescence in a total of 10,000 events (cells) per condition was recorded in the flow cytometer. Annexin V- or PI-positive cells were counted as dead cells, the remaining cells were designated the surviving cell fraction. Loss of viability was also confirmed by trypan blue dye exclusion [31].

\section{Statistical analysis}

Data are commonly derived from experiments performed at least twice in duplicates with similar results. Quantitative data are represented as mean \pm standard deviation (SD) from the mean. Statistical significance was assessed using the student $t$-test, one-way ANOVA with Tukey's post hoc test or a two-way ANOVA wherever applicable. A $p$ value below 0.05 was considered significant. All statistical analyses were performed using Prism 5 (GraphPad Software, La Jolla, CA, USA) at $p<$ $0.05, p<0.01, p<0.001$ or $p<0.0001$.

\section{FUNDING}

This study was supported by grants from the Neuroscience Center Zurich and the Zurich Cancer League to G.T., from Oncosuisse (KLS 2579-02-2010 to M.W. and G.T.), from the Swiss National Science Foundation (SNF 310030 143991 to G.T., K.F. and M.W.), and from the University of Zurich to I.B.

\section{CONFLICTS OF INTEREST}

SK, ES, IB, and KF report no conflict of interest. GT has received travel grants from MSD and honoraria for lectures for advisory board participation from Roche Switzerland and MSD. MW has received research grants from Actelion, Bayer, Isarna, MSD, Merck Serono, PIQUR and Roche and honoraria for lectures or advisory board participation from Celldex, Isarna, Magforce, MSD, Merck Serono, Pfizer, Roche and Teva.

\section{REFERENCES}

1. Jain RK, Di Tomaso E, Duda DG, Loeffler JS, Sorensen AG, Batchelor TT. Angiogenesis in brain tumours. Nat Rev Neurosci. 2007; 8:610-622.

2. Lebrin F, Goumans MJ, Jonker L, Carvalho RL, Valdimarsdottir G, Thorikay M, Mummery C, Arthur HM, ten Dijke P. Endoglin promotes endothelial cell proliferation and TGF-beta/ALK1 signal transduction. The EMBO journal. 2004; 23:4018-4028.

3. Goumans MJ, Valdimarsdottir G, Itoh S, Rosendahl A, Sideras P, ten Dijke P. Balancing the activation state of the endothelium via two distinct TGF-beta type I receptors. The EMBO journal. 2002; 21:1743-1753.

4. Medici D, Shore EM, Lounev VY, Kaplan FS, Kalluri R, Olsen BR. Conversion of vascular endothelial cells into multipotent stem-like cells. Nat Med. 2010; 16:1400-U1480.

5. Kokudo T, Suzuki Y, Yoshimatsu Y, Yamazaki T, Watabe T, Miyazono K. Snail is required for TGF betainduced endothelial-mesenchymal transition of embryonic stem cell-derived endothelial cells. J Cell Sci. 2008; 121:3317-3324.

6. Shen W, Li S, Chung SH, Zhu L, Stayt J, Su T, Couraud PO, Romero IA, Weksler B, Gillies MC. Tyrosine phosphorylation of VE-cadherin and claudin-5 is associated with TGF-beta1-induced permeability of centrally derived vascular endothelium. European journal of cell biology. 2011; 90:323-332.

7. Galliher AJ, Schiemann WP. beta(3) Integrin and Src facilitate transforming growth factor-beta mediated induction of epithelial-mesenchymal transition in mammary epithelial cells. Breast Cancer Res. 2006; 8.

8. Bianchi A, Gervasi ME, Bakin A. Role of beta5-integrin in epithelial-mesenchymal transition in response to TGF-beta. Cell Cycle. 2010; 9:1647-1659.

9. Medici D, Potenta S, Kalluri R. Transforming growth factorbeta 2 promotes Snail-mediated endothelial-mesenchymal transition through convergence of Smad-dependent and Smad-independent signalling. Biochem J. 2011; 437:515-520.

10. Meadows KN, Iyer S, Stevens MV, Wang D, Shechter S, Perruzzi C, Camenisch TD, Benjamin LE. Akt promotes endocardial-mesenchyme transition. Journal of angiogenesis research. 2009; 1:2.

11. Batchelor TT, Reardon DA, de Groot JF, Wick W, Weller M. Antiangiogenic therapy for glioblastoma: current status and future prospects. Clin Cancer Res. 2014; 20:5612-5619.

12. Du R, Lu KV, Petritsch C, Liu P, Ganss R, Passegue E, Song H, Vandenberg S, Johnson RS, Werb Z, Bergers G. HIF1alpha induces the recruitment of bone marrow-derived vascular modulatory cells to regulate tumor angiogenesis and invasion. Cancer Cell. 2008; 13:206-220.

13. Eichmann A, Simons M. VEGF signaling inside vascular endothelial cells and beyond. Current opinion in cell biology. 2012; 24:188-193.

14. Uhl M, Aulwurm S, Wischhusen J, Weiler M, Ma JY, Almirez R, Mangadu R, Liu YW, Platten M, Herrlinger U, Murphy A, Wong DH, Wick W, et al. SD-208, a novel transforming growth factor beta receptor I kinase inhibitor, inhibits growth and invasiveness and enhances immunogenicity of murine and human glioma cells in vitro and in vivo. Cancer Res. 2004; 64:7954-7961. 
15. Rodon L, Gonzalez-Junca A, Inda Mdel M, Sala-Hojman A, Martinez-Saez E, Seoane J. Active CREB1 promotes a malignant TGFbeta2 autocrine loop in glioblastoma. Cancer discovery. 2014; 4:1230-1241.

16. Iwata J, Hacia JG, Suzuki A, Sanchez-Lara PA, Urata M, Chai Y. Modulation of noncanonical TGF-beta signaling prevents cleft palate in Tgfbr2 mutant mice. J Clin Invest. 2012; 122:873-885.

17. Goumans MJ, Valdimarsdottir G, Itoh S, Lebrin F, Larsson J, Mummery C, Karlsson S, ten Dijke P. Activin receptor-like kinase (ALK)1 is an antagonistic mediator of lateral TGFB/ALK5 signaling. Mol Cell. 2003; 12:817-828.

18. Failla CM, Odorisio T, Cianfarani F, Schietroma C, Puddu P, Zambruno G. Placenta growth factor is induced in human keratinocytes during wound healing. J Invest Dermatol. 2000; 115:388-395.

19. Hollborn M, Tenckhoff S, Seifert M, Kohler S, Wiedemann P, Bringmann A, Kohen L. Human retinal epithelium produces and responds to placenta growth factor. Graef Arch Clin Exp. 2006; 244:732-741.

20. Gerber HP, Condorelli F, Park J, Ferrara N. Differential transcriptional regulation of the two vascular endothelial growth factor receptor genes. Flt-1, but not Flk-1/ KDR, is up-regulated by hypoxia. J Biol Chem. 1997; 272:23659-23667.

21. Ulyatt C, Walker J, Ponnambalam S. Hypoxia differentially regulates VEGFR1 and VEGFR2 levels and alters intracellular signaling and cell migration in endothelial cells. Biochem Biophys Res Commun. 2011; 404:774-779.

22. Nilsson I, Shibuya M, Wennstrom S. Differential activation of vascular genes by hypoxia in primary endothelial cells. Exp Cell Res. 2004; 299:476-485.

23. Mihira H, Suzuki HI, Akatsu Y, Yoshimatsu Y, Igarashi T, Miyazono K, Watabe T. TGF-beta-induced mesenchymal transition of MS-1 endothelial cells requires Smaddependent cooperative activation of Rho signals and MRTF-A. J Biochem. 2012; 151:145-156.

24. Medici D, Shore EM, Lounev VY, Kaplan FS, Kalluri R, Olsen BR. Conversion of vascular endothelial cells into multipotent stem-like cells (vol 16, pg 1400, 2010). Nat Med. 2011; 17:514-514.
25. Mahabir R, Tanino M, Elmansuri A, Wang L, Kimura T, Itoh $T$, Ohba $Y$, Nishihara $H$, Shirato $H$, Tsuda M, Tanaka S. Sustained elevation of Snail promotes glialmesenchymal transition after irradiation in malignant glioma. Neuro Oncol. 2014; 16:671-685.

26. Dieterich LC, Mellberg S, Langenkamp E, Zhang L, Zieba A, Salomaki H, Teichert M, Huang H, Edqvist PH, Kraus T, Augustin HG, Olofsson T, Larsson E, et al. Transcriptional profiling of human glioblastoma vessels indicates a key role of VEGF-A and TGFbeta2 in vascular abnormalization. J Pathol. 2012; 228:378-390.

27. Batchelor TT, Mulholland P, Neyns B, Nabors LB, Campone M, Wick A, Mason W, Mikkelsen T, Phuphanich S, Ashby LS, DeGroot J, Gattamaneni R, Cher L, et al. Phase III Randomized Trial Comparing the Efficacy of Cediranib As Monotherapy, and in Combination With Lomustine, Versus Lomustine Alone in Patients With Recurrent Glioblastoma. J Clin Oncol. 2013; 31:3212-3218.

28. Gilbert MR, Dignam JJ, Armstrong TS, Wefel JS, Blumenthal DT, Vogelbaum MA, Colman H, Chakravarti A, Pugh S, Won M, Jeraj R, Brown PD, Jaeckle KA, et al. A Randomized Trial of Bevacizumab for Newly Diagnosed Glioblastoma. New Engl J Med. 2014; 370:699-708.

29. Chinot OL, Wick W, Mason W, Henriksson R, Saran F, Nishikawa R, Carpentier AF, Hoang-Xuan K, Kavan P, Cernea D, Brandes AA, Hilton M, Abrey L, et al. Bevacizumab plus Radiotherapy-Temozolomide for Newly Diagnosed Glioblastoma. New Engl J Med. 2014; 370:709-722.

30. Hamerlik P, Lathia JD, Rasmussen R, Wu QL, Bartkova J, Lee M, Moudry P, Bartek J, Fischer W, Lukas J, Rich JN, Bartek J. Autocrine VEGF-VEGFR2-Neuropilin-1 signaling promotes glioma stem-like cell viability and tumor growth. J Exp Med. 2012; 209:507-520.

31. Happold C, Roth P, Silginer M, Florea AM, Lamszus K, Frei K, Deenen R, Reifenberger G, Weller M. Interferonbeta induces loss of spherogenicity and overcomes therapy resistance of glioblastoma stem cells. Molecular cancer therapeutics. 2014; 13:948-961. 